\title{
Article
}

\section{Fuel Exports, Aid and Terrorism}

\author{
Asongu, Simplice and Nwachukwu, Jacinta Chikaodi
}

Available at http://clok.uclan.ac.uk/25160/

Asongu, Simplice and Nwachukwu, Jacinta Chikaodi ORCID: 0000-0003-29879242 (2017) Fuel Exports, Aid and Terrorism. Multinational Business Review, 25 (3). pp. 239-267. ISSN 1525-383X

It is advisable to refer to the publisher's version if you intend to cite from the work. http://dx.doi.org/10.1108/MBR-03-2017-0013

For more information about UCLan's research in this area go to http://www.uclan.ac.uk/researchgroups/ and search for < name of research Group>.

For information about Research generally at UCLan please go to http://www.uclan.ac.uk/research/

All outputs in CLoK are protected by Intellectual Property Rights law, including Copyright law. Copyright, IPR and Moral Rights for the works on this site are retained by the individual authors and/or other copyright owners. Terms and conditions for use of this material are defined in the policies page.

\section{CLoK}

Central Lancashire online Knowledge www.clok.uclan.ac.uk

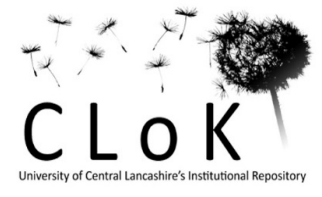




\section{MPRA \\ Munich Personal RePEc Archive}

\section{Fuel Exports, Aid and Terrorism}

Simplice Asongu and Jacinta Nwachukwu

January 2017

Online at https://mpra.ub.uni-muenchen.de/81188/

MPRA Paper No. 81188, posted 7 September 2017 01:21 UTC 


\section{$\underline{\text { A G D I Working Paper }}$}

\section{$\mathrm{WP} / 17 / 016$}

\section{Fuel Exports, Aid and Terrorism}

Forthcoming in: Multinational Business Review

\section{Simplice A. Asongu}

African Governance and Development Institute, P.O. Box 8413 Yaoundé, Cameroon.

E-mail: asongusimplice@yahoo.com

\section{Jacinta C. Nwachukwu}

Department of Economics, Finance and Accounting, Faculty of Business, Environment and Society,

Coventry University

Priory Street, Coventry, CV1 5DH, UK

Email: jacinta.nwachukwu@ coventry.ac.uk 
Research Department

\title{
Fuel Exports, Aid and Terrorism
}

\section{Simplice A. Asongu \& Jacinta C. Nwachukwu}

January 2017

\begin{abstract}
This study employs interactive quantile regressions to assess the conditional role of foreign aid in reducing the potentially negative effect of terrorism on fuel exports in 78 developing countries for the period 1984-2008. Bilateral and multilateral aid indicators are used whereas terrorism includes: domestic, transnational, unclear and total terrorism dynamics. Interactive quantile regressions are used. The following findings are established. First, the effects of terrorism are both positive and negative across quantiles and specifications, with the impact most apparent in the highest and lowest quantiles. Second, while bilateral aid consistently decreases (increases) fuel exports at the top (bottom) quantiles, multilateral aid regularly decreases fuel exports in the top quantiles. Third, for negative thresholds in the $50^{\text {th }}$ quartile and $90^{\text {th }}$ decile, interaction effects between bilateral aid and terrorism dynamics are overwhelmingly not significant. Conversely, for transnational terrorism, the interaction effects between multilateral aid and terrorism dynamics significantly have negative thresholds. The hypothesis of a positive threshold is only confirmed for transnational terrorism and multilateral aid at the $90^{\text {th }}$ decile. Justifications for unexpected signs and implications for fuel export policy and the management of multinational companies are discussed. This study contributes to the literature on the role of external flows in reducing the negative externalities of terrorism on development outcomes.
\end{abstract}

JEL Classification: F40; F23; F35;Q34 ; O40

Keywords: Exports; Foreign Aid; Terrorism; Natural Resources; Development 


\section{Introduction}

Over the past decades, terrorism and conflicts have substantially affected petrodollar or government revenues in oil-exporting countries. Some notable examples include: Nigeria's oil Delta region with sabotage activities from the Movement for the Emancipation of the Niger Delta (Obi, 2010; Onuoba, 2010; Akpan et al., 2013; Taylor, 2014); recent Al-Qaeda attacks in In Amenas fuel installations of Algeria (Onyeji et al., 2014 ); massive disruption of Libyan oil production in the post-Gaddafi era (Gaub, 2014) and the Middle East conflict in which the Islamic State of Iraq and Levant (ISIL) now controlling about 90 percent of Syrian oil installations can only trade its piecemeal fuel exploration in black and informal markets (Le Billon, 2015; Celso, 2015).

In light of the above, a growing body of the literature has been focusing on instruments by which conflicts and terrorism can be mitigated. To the best of our knowledge, some of the documented instruments have included: the need for transparency (Bell et al., 2014), the relevance of respecting the rule of law (Choi, 2010), imperative for educational mechanisms (Brockhoff et al., 2014) like bilingualism (Costa et al., 2008), greater publicity and press freedom (Hoffman et al., 2013), behavioural investigations of attitudes towards terrorism (Gardner, 2007) and use of military tactics and strategies (Feridun \& Shahbaz, 2010).

Another interesting strand of studies has been oriented towards assessing linkages between terrorism, violence, political instability and macroeconomic factors. As far as we are aware, this stream of the literature has focused on inter alia: (i) the effect of terrorism on foreign direct investment (FDI) (Abadie and Gardeazabal, 2008), (ii) interconnections between terrorism and innovation (Koh, 2007), (iii) the growth-terrorism nexus, with bidirectional causality (Gries et al., 2011; Shahbaz et al., 2013; Shahzad et al., 2015), causality to terrorism from growth (Piazza, 2006; Choi, 2015), causality from terrorism to growth (Gaibulloev \& Sandler, 2008, 2009, 2011; Öcal \& Yildirim, 2010; Meierrieks \& Gries, 2013) and (iv) the relevance of foreign aid in mitigating the potentially negative effect of terrorism on development outcomes like external flows (Bandyopadhyay et al., 2014), conditional on initial levels of external flows (Asongu et al., 2015) or corruption-control levels in the domestic countries (Efobi et al., 2015). The present line of inquiry is closest to the last stream. Accordingly, we aim to investigate the role of development assistance in reducing the potentially negative effect of terrorism on fuel exports. 
The literature on the terrorism-trade nexus can be discussed in three main streams, notably: (i) the impact of terrorism on trade, (ii) the effect of trade on terrorism and (iii) issues relating to the empirical modelling of the underlying relationships.

First, as concerns the incidence of terrorism on trade, four studies come to mind. First, Richardson (2004) has engaged security measures that were adopted after the September $11^{\text {th }}$ 2011 terrorists' attacks in the United States. The plethora of resulting security initiatives has been partly motivated by the need to prevent the negative consequences of terrorism on world trade. (2) The impact of welfare and terror on trade openness has been investigated by Nitsch and Schumacher (2004). Employing an augmented gravity model on 200 countries for the period 1960-2003, the authors have used bilateral trade, violence and terrorism indicators to conclude that terrorism has a negative effect on trade openness. According to the narrative, a doubling of incidents of terrorism reduces bilateral trade by about 4 percent. (3) De Sousa et al. (2009a) have accessed the interplay between trade and nearness to the source of terror to establish the following key findings. (i) More robust investigations are needed to improve scholarly understanding as to how trade in the source-country and neighbouring countries are affected by terrorists incidents' in the former. (ii) There is need for theoretical underpinnings to enhance clarity on linkages between transnational terrorism, trade and security policy. (4) As an extension of the previous study, De Sousa et al. (2009b) have examined the effect of international terrorism diffusion on trade and security. The empirical underpinnings are based on the assumption that proximity to terrorism is inversely related to the corresponding negative spillovers on trade. Moreover, the intuition for the study is consistent with the hypothesis that terror in a source country has negative effects to both the source-country itself and neighbouring nations simultaneously. On the other hand, countries that are more distantly-located from the 'source-country of terror' could be endowed with positive externalities in terms of incremental trade, related/corresponding to the decreasing trade from the country affected by terror and/or countries in the immediate neighbourhood of the country affected by terror. Overall, three main findings were established. They are: (i) there is a direct negative effect of transnational terrorism on trade, (ii) an indirect negative effect of terrorism from the source-country to neighbouring countries is apparent and (iii) terrorism increases trade in countries that are remote from the 'source-country of terror'.

Second, coming to the impact of trade on terrorism, two studies in the limited literature have caught our attention. These have essentially been focused on the commercialisation of illegal drugs. (1) Piazza (2011) examined the link between the 'drugs trade' and terrorism on 
the hypothesis that illicit 'drugs trade' fuels terrorism. The author has concluded that 'cocaine production' and illicit drugs are significant drivers of transnational and domestic terrorism. Conversely, banning drugs and eradicating illicit crop cultivation leads to the opposite outcome. As an extension, Piazza (2012) investigated the connection between the opium trade and terrorism in 34 Afghan provinces for the period 1996-2008 using binomial regressions. The author concluded that provinces where opium is substantially produced are associated with relatively higher rates of terrorist attacks and casualties. Therefore, there is a direction of causality flowing from the production of opium to terrorism.

Third, in the strand on empirical modelling concerns pertaining to the trade-terrorism relationship, Mirza and Verdier (2008) surveyed the literature and documented four main cautions that should be borne in mind by researchers when investigating the underlying association. They comprise the need to: (i) account for omitted indictors that are very likely to be correlated with trade and terrorism, (ii) acknowledge the inter-temporal persistence of terrorism, (iii) distinguish between the effects of country-specific occurrences from the impact of incidents focused on the source-country and (iv) control for endogeneity.

The above literature leaves room for improvement in at least four major areas. They relate to the imperative of: (i) accounting for more dynamics of terrorism, (ii) exploring linkages between foreign policy in the underlying trade-terrorism relationship, (iii) considering specific dimensions of trade openness and (iv) adopting more robust empirical techniques that control for initial trade levels. We may deal with each in turn.

First, building on the caution sustained by Choi (2015) on the imperative of exploring more indicators when assessing the nexus between terrorism and macroeconomic indicators, we involve a plethora of terrorism indicators in order to provide room for more policy implications, notably: domestic, transnational, unclear and total terrorism. Consideration of these measurements of terrorism is in accordance with recent studies on the nexus between terrorism and macroeconomic indicators (Efobi et al., 2015). Moreover, the adoption of more terrorism indicators is partially motivated by the need to augment the engaged literature, which has been focused on few indicators, notably: (i) transnational terrorism in De Sousa et al. (2009ab) and (ii) domestic and transnational terrorism in Piazza (2011).

Second, in line with Choi (2015), we attempt to create space for a detailed discussion on policy outcomes, by limiting our investigation to the recent body of literature that has employed foreign aid as a policy variable in mitigating the hypothetically/documented negative effects of terrorism on foreign investment (Bandyopadhyay et al., 2014; Asongu et 
al., 2015; Efobi et al., 2015). To this end, we employ two foreign aid variables, namely multilateral and bilateral aid. The motivation for involving this policy indicator is based on the exploratory (Richardson, 2014) and empirical (De Sousa et al., 2009ab) underpinnings which show that terrorism reduces trade openness.

Third, it is imperative to engage trade-specific dimensions for more targeted policy implications. To this end: (i) contrary to previous studies that have used broad trade openness indicators (Richardson, 2004; Nitsch \& Schumacher, 2004; De Sousa et al., 2009ab) and (ii) consistent with the stream of literature using export-specific variables (Piazza, 2011, 2012), we confined the analytical scope to fuel exports. The choice of fuel exports has a twofold inspiration, on the one hand, the recent growth resurgence in developing countries has been substantially driven by natural resources, (Amavilah, 2015) especially fuel exports, and (ii) on the other, as we have seen in the first paragraph here, terrorist activities have substantially affected fuel exports in recent decades.

Fourth, motivated by the recommendation of Mirza and Verdier (2008) on the imperative for more robust empirical strategies, we adopt an estimation technique that is robust to outliers. Moreover, the adopted Qauntile regression strategy also enables us to distinguish between initial levels of fuel exports. Accordingly, blanket policies based on the investigated relationships may not be effective unless they are contingent on initial levels of fuel exports and tailored distinctly across high- and low-'fuel exporting' countries.

With the above interesting background, this line of inquiry is positioned on investigating the role of development assistance in dampening the negative effects of terrorism on fuel exports. The empirical evidence is based on 78 developing countries for the period 1984 to 2008 . There are at least four reasons for our choice of periodicity and sample. First, the starting year is 1984 because institutional data from the International Country Risk Guide (ICRG) is only available from this year. Second, the focus on developing countries is in tune with Gaibulloev and Sandler (2009) who have established that negative consequences from terrorism are more apparent in developing countries vis-à-vis advanced nations. This is essentially because; the latter countries have the financial, logical and technological means needed to absorb the negative effects of terrorism without substantial macroeconomic consequences. Third, development assistance is principally channelled from more advanced economies to less developed countries. Hence, the empirical scope on these underdeveloped countries, contingent on a foreign aid variable is naturally justified. Fourth, a motivation for the present study is also to compare findings with those of the available literature that 
employed the same sample and periodicity, particularly: Bandyopadhyay et al. (2014), Efobi et al. (2015) and Asongu et al. (2015).

The positioning of this inquiry steers clear of recent literature on international business and strategic management on the relationship between conflicts and development outcomes. In particular, studies on the identification of antecedents for, and consequences of low intensity inter-unit conflict in Multinational Companies (MNCs) (Lauring et al., 2017), the exploration of how and why MNCs proactively address the concern of uncertainty by valuing locational ambidexterity in decision making (Huang \& John, 2017), the relevance of political risk (law and order, internal conflict and ethnic tension) in determining foreign direct and indirect investments in developing countries (Al-Khouri, 2015), strategies of MNCs in which terrorism is factored-in as a fundamental threat (Suder \& Czinkota, 2005), macroeconomic models of political risk assessments (Alon \& Martin, 1998) and the effects of risks (political, economic, default and credit) on the allocative efficiency of global financial markets (Ramcharran, 2003).

The rest of the study is structured as follows. Stylized facts, theoretical underpinnings and international business and strategy are presented in Section 2. Section 3 presents the data and methodology. The empirical results, discussion and policy implications are covered in Section 4. Section 5 concludes with suggestions for future research.

\section{Stylized Facts, Theoretical Underpinnings and International Business and Strategy}

\section{1 Stylized facts and theoretical underpinnings}

According to the Global Peace Index (GPI), over 13 percent of the global Gross Domestic Product (GDP) in 2014 was lost to violence-related expenditure (Anderson, 2015). According to the report, approximately 14.3 trillion USD or 13.4 percent of Global GDP was invested in curtailing violence, crimes, conflicts, political instability and terrorism. The underlying expenditure is equivalent to the combined GDP of Germany, Spain, France, Canada, Brazil and the United Kingdom. Consistent with the report, a substantial amount of the expenditure is skewed towards terrorism-related activities. Projections show that terrorists' activities are likely to increase in the coming years owing to burgeoning terrorism networks which have been proliferating in operational scope, representing about a 61 percent rise in killings as of 2014 compared to 2008.

The 2014 GPI account is supported by the 2014 Global Terrorism Index (GTI, 2014, p. 13), which concluded that in the aftermath of the 2011 Arab Spring, terrorism has 
substantially increased. As cases of reference to this point, six main stylized facts are apparent to the best of our knowledge (Asongu et al. 2015). First, Libya in the post-Gaddafi era has become a failed state, with widespread anarchy and societal breakdown, characterised by various rebel factions and two rival governments clamouring to dictate the law of the land and run a substantially deteriorated oil-dependent economy. Second, the situation in Yemen has severely deteriorated with the inability of the government to honour the terms of its socioeconomic contracts with the Yemini citizens after the overthrow of President Ali Abdullah Saleh. As we write this paper, a proxy war is being fought between Iran and Saudi Arabia who are supporting rebels and the government respectively. Third, the 2015 Garissa university killings and 2013 Westgate shopping mall attacks by Al-Shabab in Kenya have illustrated that the Somali Al-Quaeda affiliated Al-Shabab can inflict substantial transnational terrorism causalities which have significant disruptive consequences to education and tourism. Fourth, in Tunisia after a wave of post-Arab Spring political assassinations, the newly democratically elected government is being seriously confronted with a wave of touristtargeted attacks, namely the: the Bardo National Museum and Sousse attacks in March and June of 2015 respectively. Fifth, the Boko Haram of Nigeria is extending its terrorism sphere to the neighbouring countries of Cameroon, Niger and Chad. Sixth, externalities of the Iraq and Syria conflicts have produced a very powerful ISIL that is now exerting substantial geopolitical effects throughout the world, namely the: (i) December 2014 hostage crisis in Sydney-Australia, (ii) January 2015 foiled Verviers-Belgium attacks, (iii) January 2015 the 'Charlie Hebdo' attacks in Paris-France and (iv) the foiled February 2015 Australian attacks, inter alia.

Whereas there are some externalities in the developed world, it is important to note that a substantial number of terrorist activities are perpetrated in the developing world (Anderson, 2015). This has increased poverty-related concerns in policy-making circles, given that the year 2014 registered the highest number of internally displaced persons since the Second World War. This finding by the 2015 GPI report ${ }^{1}$ presents a bleak prospect for developing countries when combined with the mid-April 2015 publication by the World Bank of its World Development Indicators. The latter report concluded that many developing countries, especially those in Sub-Saharan Africa have still a long way to go in attaining the Millennium Development Goals (MDGs) extreme poverty target (World Bank, 2015; Caulderwood, 2015). Given that most of the growth needed to alleviate poverty in developing

\footnotetext{
${ }^{1}$ The 2014 GPI should not be confused with the 2015 GPI report because the latter documents the former.
} 
countries is resource-driven, understanding the role of foreign aid in reducing the potentially negative effect of terrorism on fuel exports is a line of inquiry of considerable policy relevance.

Consistent with the recommendation of De Sousa et al. (2009a) on the need to clearly articulate theoretical concepts motivating studies investigating the relationship between terrorism and macroeconomic variables, we briefly highlight the theories underpinning the present line of inquiry. In line with the underlying terrorism literature (Efobi et al., 2015; Asongu et al., 2015), two main theories which are documented by Akinwale (2010, p. 125) are used to provide the foundations for the current study, namely: the Conflict Management Model (CMM) of Thomas-Kilman (1992) and the Social Control Theory (SCT) from Black (1990). Under the CMM, intentions of strategic character have a high likelihood of rotating around a two-factor matrix (of assertiveness and cooperation), when combined with collaboration produce five principal styles of conflict management, namely: avoidance, compromise, collaboration, competition and accommodation. On the other hand, according to the SCT, relationships between organisations, individuals and groups influence the exercise of one out of five main channels of social control, involving: negotiation, avoidance, settlement, self-help and tolerance. This theoretical basis is consistent with the conflict management and peace literature (Borg, 1992; Volkema \& Bergmann, 1995) and in agreement with the present study because foreign aid is employed as a policy variable in order to provide an enabling environment for the mitigation of terrorism, especially: (i) the improvement of government expenditure according to Gaibulloev and Sandler (2009) and (ii) education and the rule of law (Heyneman, 2002; Beets, 2005; Heyneman, 2008ab; Oreopoulos \& Salvanes, 2009), among others.

\subsection{International business and strategy}

There are various international business approaches that are adopted by managers of MNCs to reduce the effects of terrorism on the cost of doing business internally. Consistent with Mazzarella (2005), this section is organised in two main strands, namely: (i) identifying the cost of terrorism in international business and (ii) managing the risk associated with terrorism.

With respect to the management of the risk that terrorism poses to MNCs, two points are worth emphasising. They are: (i) terrorism management methods and (ii) risk modelling. On the one hand, minimising the cost of terrorism fundamentally depends on risk modelling effectiveness. The standard contemporary practice for most managers consists of estimating 
future loses with computer risk modelling which uses physical security analysis as inputs to determine the probability of attacks from terrorists and the potential level of damages. This ultimately informs the managers on the level of terrorism related risk insurance coverage needed for a particular business operation. On the other hand, there are various terrorism risk management methods that are adopted by managers, notably: maintaining good human rights and environmental records within regions in which they operate; using subcontractors to reduce further risk; hiring more security consultants and personnel; hardening of work sites and physical assets and training of personnel to avoid being the target of terrorism.

The potential costs of terrorism in international business can be seen from four main angles, namely: (i) improving the physical security of personnel, plant and equipment, (ii) hiring security consultants, (iii) improving global supply chains by securing the transportation of commodities as well as the risks related to the disruption of global sources of supply, (iii) reducing direct operations and investment in areas of high risk and (iv) political risk insurance.

The above theoretical underpinnings are broadly consistent with the recent international business literature on the strategies of managing the negative externalities of terrorism, namely: planning for potential effects of terrorism (Harvey et al., 2017) the management of people in hostile environments (Barder et al., 2015), especially expatriate personnel (Barder \& Berg, 2014a; Bader et al., 2016; Barder \& Berg, 2014b) and Corporate Social Responsibility by MNCs as a strategic management tool (Agwu \& Taylor, 2015).

\section{Data and Methodology}

\subsection{Data}

We examine a panel of 78 developing countries with data for the period 1984-2008 from Bandyopadhyay et al. (2014) and Efobi et al. (2015). The choice of sample and periodicity has already been justified in the introduction ${ }^{2}$. The data entails non-overlapping intervals in terms of three-year averages. The dependent variable is 'fuel exports' while the

\footnotetext{
${ }^{2}$ The adopted countries include: “Albania, Costa Rica, India, Namibia, Syria, Algeria, Cote d'Ivoire, Indonesia, Nicaragua, Tanzania, Angola, Dominican Republic, Iran, Niger, Thailand, Argentina, Ecuador, Jamaica, Nigeria, Togo, Bahrain, Egypt, Jordan, Pakistan, Trinidad and Tobago, Bangladesh, El Salvador, Kenya, Panama, Tunisia, Bolivia, Ethiopia, Lebanon, Papua New Guinea, Turkey, Botswana, Gabon, Libya, Paraguay, Uganda, Brazil, Gambia, Madagascar, Peru, Uruguay, Burkina Faso, Ghana, Malawi, Philippines, Venezuela, Cameroon, Guatemala, Malaysia, Saudi Arabia, Vietnam, Chile, Guinea, Mali, Senegal, Yemen, China, Guinea-Bissau, Malta, Sierra Leone, Zambia, Colombia, Guyana ,Mexico, South Africa, Zimbabwe, Congo, D. Republic, Haiti, Morocco, Sri Lanka, Congo Republic, Honduras, Mozambique and Sudan”.
} 
independent variables of interest are indicators of terrorism, namely: unclear, domestic, transnational and total terrorism dynamics. Two foreign aid variables are employed: multilateral and bilateral aid.

The variables are originally from three principal sources, namely: (i) the incidence of terrorism from Enders et al. (2011) and Gailbulloev et al. (2012), (ii) the Global Terrorism Database and (iii) the World Development Indicators of the World Bank. Three main justifications influence the choice of periodicity and sample. First, in accordance with Gaibulloev and Sandler (2009), relative to more advanced economies, the negative consequences of terrorism are visible in developing nations. As we said earlier, this asymmetric effect is essentially because, developing countries do not have the adequate financial, logistical and technological mechanisms that are needed to absorb the negative consequences associated with terrorism. Second, foreign aid is logically channelled to developing nations from their more developed counterparts. Third, we aim to compare the findings established with a stream of literature that has used the same database, notably Bandyopadhyay et al. (2014) and Efobi et al. (2015).

We define terrorism as the actual and threatened use of force by sub-national actors with the principal mission of using intimidation to secure political ambitions (see Enders \& Sandler, 2006). The terrorism indicators measure the number of yearly terrorism incidents registered in a country. In order to reduce mathematical concerns that are linked to logtransforming zeros and correct the positive skew in the data, the study uses the natural logarithm of terrorism incidents by adding one to the base. Such a transformation procedure is consistent with recent terrorism literture (Choi \& Salehyan, 2013; Bandyopadhyay et al., 2014; Efobi \& Asongu, 2016). Terrorism-specific definitions are from Efobi et al. (2015, p. 6). Domestic terrorism "includes all incidences of terrorist activities that involve[s] the nationals of the venue country: implying that the perpetrators, the victims, the targets and supporters are all from the venue country" (p.6). Transnational terrorism is "terrorism including those acts of terrorism that concern[s] at least two countries. This implies that the perpetrator, supporters and incidence may be from/in one country, but the victim and target is from another". Unclear terrorism is that, "which constitutes incidences of terrorism that can neither be defined as domestic nor transnational terrorism" (p.6). Total terrorism is the sum of domestic, transnational and unclear terrorisms.

The dependent variable, aid and control covariates are from the World Bank Development Indicators. We also take the natural logarithm of fuel exports. Therefore exports 
of value zero are considered as missing data after the log transformation. The three countries without any data on fuel exports are Guinea Bissau, Sierra Leone and the Democratic Republic of Congo. The concern of zeros is more apparent in the count data (i.e. terrorism variables) than in fuel exports. The development assistance data are disbursements of aid from Development Assistance Committee countries.

The control variables comprise: trade openness, exchange rate, infrastructure, political globalisation, inflation and internal conflicts. The choice of control variables is in accordance with the FDI-terrorism literature (Bandyopadhyay et al., 2014; Efobi et al., 2015). Based on our expectations, infrastructural development, increasing exchange rates and trade openness should have positive effects on fuel exports (Akpan, 2014), while civil/internal conflicts and inflation should exert opposite effects. For example, high exchange rates have been documented to boost exports in developing countries (Rodrik, 2008). Whereas stable and low inflation is conducive for economic prosperity, chaotic inflation may decrease fuel exports owing to a negative economic outlook. This is essentially because investors have been shown to prefer strategies of investment that are void of ambiguity (Le Roux \& Kelsey, 2015ab). The expected sign of political globalisation cannot be established a priori because it depends to a great extent on leverage in decision making at the international level. The definitions of variables are provided in Appendix 1.

The summary statistics of the variables are provided in Appendix 2. From it, two points are note worthy. On the one hand, the means of the variables are comparable. On the other, based on the variations, we can be confident that reasonable estimated relations would emerge. The objective of the correlation matrix presented in Appendix 3 is to examine and avoid potential concerns of multicollinearity which we have highlighted in bold. We observe from this matrix that terrorism and foreign aid variables are highly correlated among themselves. Hence, we avoid employing more than two foreign aid and terrorism variables in the same specification.

\subsection{Methodology}

In accordance with the underlying literature on conditional macroeconomic determinants (Billger \& Goel, 2009; Asongu et al., 2015), in order to examine if initial levels of fuel exports matter in how the independent variables interplay in influencing fuel exports, we employ a quantile regression $(\mathrm{QR})$ estimation strategy. It entails, investigating the 
determinants of fuel exports throughout the conditional distributions of fuel exports (Keonker \& Hallock, 2001).

Previous literature on linkages between terrorism and macroeconomic variables has reported parameters estimates at the conditional mean of macroeconomic indicators (Bandyopadhyay et al., 2014; Efobi et al., 2015). Whereas mean impacts are certainly relevant, we extend the underlying stream of terrorism studies by employing QR which distinguishes between initial export levels. For instance, while Ordinary Least Squares (OLS) is based on the supposition that error terms and the dependent variable are normally distributed, the QR approach is not founded on the hypothesis of normally distributed error terms. Hence, this strategy enables us to examine the impacts on the dependent variable with particular emphasis on low- medium- and high-fuel exporting countries. Accordingly, with $\mathrm{QR}$, parameter estimates are derived at multiple points on the conditional distributions of fuel exports (Keonker \& Hallock, 2001). The QR technique is increasingly being employed in development literature, notably in: corruption (Billger \& Goel, 2009; Okada \& Samreth, 2012; Asongu, 2013) and financial development (Asongu et al., 2017; Asongu \& Nwachukwu, 2017) studies.

The $\theta^{\text {th }}$ quantile estimator of fuel exports is obtained by solving for the optimization problem in Eq. (1), which is presented without subscripts for ease of presentation and of simplicity.

$$
\min _{\beta \in R^{k}}\left[\sum_{i \in\left\{i: y_{i} \geq x^{\prime} \beta\right.} \theta\left|y_{i}-x_{i^{\prime}} \beta\right|+\sum_{i \in\left\{i: y_{i}<x i^{\prime} \beta\right.}(1-\theta)\left|y_{i}-x_{i^{\prime}} \beta\right|\right],
$$

where $\theta \in(0,1)$. As opposed to OLS which is fundamentally based on minimizing the sum of squared residuals, with $\mathrm{QR}$, the weighted sum of absolute deviations are minimised, for instance the $25^{\text {th }}$ or $75^{\text {th }}$ quartiles (with $\theta=0.25$ or 0.75 respectively) by approximately weighing the residuals. The conditional quantile of fuel exports or $y_{i}$ given $x_{i}$ is:

$$
Q_{y}\left(\theta / x_{i}\right)=x_{i} \beta_{\theta},
$$

where unique slope parameters are modelled for each $\theta^{\text {th }}$ specific quantile. This formulation is analogous to $E(y / x)=x^{\prime} \beta$ in the OLS slope where parameters are investigated only at the mean of the conditional distribution of fuel exports. For the model in Eq. (2) the dependent variable $y_{i}$ is the fuel exports indicator while $x_{i}$ contains a constant term, trade 
openness, inflation, infrastructure, exchange rates, political globalisation and civil/internal conflicts. The specifications in Eq. (1) are tailored to mitigate the multicollinearity concerns highlighted in Appendix 3.

Considering that the strategy of estimation we have adopted involves interactive regressions, we briefly engage Brambor et al. (2006) on the pitfalls of interactive regressions. For the estimation output to have economic meaning, the corresponding estimated interactive coefficients should be interpreted as conditional marginal effects. Moreover, the modifying or foreign aid indicator should be within the range provided by the summary statistics for the overall marginal effect to have economic meaning.

\section{Empirical Analysis}

\subsection{Presentation of results}

Table 1 and Table 2 present results corresponding to bilateral aid and multilateral aid regressions respectively. All the tables entail four-sets of specifications. They are: (i) domestic and transnational terrorism modelling in Panel A and (ii) unclear and total terrorism estimations in Panel B. More specifically, the left-hand-side (LHS) of Panel A (B) display findings for domestic (unclear) terrorism whereas the right-hand-side (RHS) of Panel A (B) show results for transnational (total) terrorism. For either table, we consistently notice that the QR estimates are different from the OLS estimates in terms of signs and significance. This further justifies the relevance of the QR strategy.

The following findings can be established with respect to Table 1 on linkages between fuel exports, bilateral aid and terrorism dynamics. First, with the exception of domestic terrorism which is not significant across fuel export distributions, the effects of terrorism are consistently significant in the $50^{\text {th }}$ quartile and $90^{\text {th }}$ decile. While these underlying effects are positive for unclear terrorism, the impact in the $50^{\text {th }}$ quartile and $90^{\text {th }}$ decile are respectively positive and negative for transnational and total terrorism. Second, bilateral aid consistently increases (decreases) fuel exports at the bottom (top) quantiles. Third, interaction effects between bilateral aid and terrorism dynamics are overwhelmingly not significant, but for the $50^{\text {th }}$ quartile and $90^{\text {th }}$ decile on the LHS of Panel B in unclear terrorism regressions for which the effects are negative. The corresponding modifying bilateral aid thresholds are within the range (0.765 to 8.362$)$ provided by the summary statistics, notably: (i) $5.702(0.211 / 0.037)$ for the $50^{\text {th }}$ quartiles and (ii) $4.750(0.133 / 0.028)$ for the $90^{\text {th }}$ decile. Fourth, most of the control variables are significant with the expected signs. Infrastructural development and political 
globalisation are positively associated with resource exports (Apkan, 2014). The sparsely positive effect of civil/internal conflict is consistent with the effects of terrorism while the scantily positive impact of inflation may be traceable to stable consumer prices (with a mean value of 2.414).

Table 1: Fuel Exports, Bilateral Aid, Terrorism

\begin{tabular}{|c|c|c|c|c|c|c|c|c|c|c|c|c|}
\hline & \multicolumn{12}{|c|}{ Dependent Variable: Fuel Exports (Ln) } \\
\hline & \multicolumn{12}{|c|}{ Panel A: Domestic Terrorism and Transnational Terrorism } \\
\hline & \multicolumn{6}{|c|}{ Domestic Terrorism (Domter) } & \multicolumn{6}{|c|}{ Transnational Terrorism (Tranater) } \\
\hline & OLS & Q.10 & Q.25 & Q.50 & Q.75 & Q.90 & OLS & Q.10 & Q.25 & Q.50 & Q.75 & Q.90 \\
\hline Constant & $\begin{array}{l}-5.63 * * \\
(0.035)\end{array}$ & $\begin{array}{l}-13.41 * * \\
(0.013)\end{array}$ & $\begin{array}{l}-8.511 * * \\
(0.012)\end{array}$ & $\begin{array}{l}-6.925 * * \\
(0.034)\end{array}$ & $\begin{array}{l}1.394 \\
(0.616)\end{array}$ & $\begin{array}{l}2.826 * * \\
(0.052)\end{array}$ & $\begin{array}{l}-5.873 * * \\
(0.029)\end{array}$ & $\begin{array}{l}-14.76 * * \\
(0.016)\end{array}$ & $\begin{array}{l}-7.634 * \\
(0.055)\end{array}$ & $\begin{array}{l}-8.09 * * * \\
(0.007)\end{array}$ & $\begin{array}{l}0.779 \\
(0.775)\end{array}$ & $\begin{array}{l}2.975 * * \\
(0.010)\end{array}$ \\
\hline Domter & $\begin{array}{l}0.005 \\
(0.636)\end{array}$ & $\begin{array}{l}0.004 \\
(0.835)\end{array}$ & $\begin{array}{l}-0.0007 \\
(0.950)\end{array}$ & $\begin{array}{l}0.026 \\
(0.104)\end{array}$ & $\begin{array}{l}0.004 \\
(0.663)\end{array}$ & $\begin{array}{l}-0.006 \\
(0.127)\end{array}$ & --- & --- & -- & -- & -- & --- \\
\hline Tranater & --- & --- & --- & --- & --- & --- & $\begin{array}{l}0.107 \\
(0.148)\end{array}$ & $\begin{array}{l}-0.010 \\
(0.952)\end{array}$ & $\begin{array}{l}0.152 \\
(0.275)\end{array}$ & $\begin{array}{l}0.187 * \\
(0.092)\end{array}$ & $\begin{array}{l}0.096 \\
(0.280)\end{array}$ & $\begin{array}{l}-0.075^{*} \\
(0.068)\end{array}$ \\
\hline LnBilaid & $(0.403)$ & $0.586^{* *}$ & $(0.320)$ & $(0.137)$ & -0.234 & $\begin{array}{l}- \\
0.195 * * * \\
(0.00)\end{array}$ & 0.136 & $0.530^{*}$ & $0.369 * *$ & $0.367^{* *}$ & -0.232 & $-0.200 * * *$ \\
\hline Domter* LnBilaid & $\begin{array}{l}-0.001 \\
(0.568)\end{array}$ & $\begin{array}{l}0.0004 \\
(0.915)\end{array}$ & $\begin{array}{l}-0.0004 \\
(0.838)\end{array}$ & $\begin{array}{l}-0.004 \\
(0.150)\end{array}$ & $\begin{array}{l}-0.001 \\
(0.429)\end{array}$ & $\begin{array}{l}0.0004 \\
(0.573)\end{array}$ & --- & --- & --- & --- & --- & -- \\
\hline Tranater* LnBilaid & --- & --- & --- & --- & --- & --- & $\begin{array}{l}-0.018 \\
(0.180)\end{array}$ & $\begin{array}{l}0.005 \\
(0.885)\end{array}$ & $\begin{array}{l}-0.024 \\
(0.311)\end{array}$ & $\begin{array}{l}-0.029 \\
(0.143)\end{array}$ & $\begin{array}{l}-0.022 \\
(0.182)\end{array}$ & $\begin{array}{l}0.011 \\
(0.190)\end{array}$ \\
\hline LnTrade & $\begin{array}{l}-0.296 \\
(0.283)\end{array}$ & $\begin{array}{l}-1.051 * \\
(0.099)\end{array}$ & $\begin{array}{l}-0.568 \\
(0.131)\end{array}$ & $\begin{array}{l}-0.137 \\
(0.695)\end{array}$ & $\begin{array}{l}0.236 \\
(0.380)\end{array}$ & $\begin{array}{l}0.166 \\
(0.190)\end{array}$ & $\begin{array}{l}-0.252 \\
(0.359)\end{array}$ & $\begin{array}{l}-1.170 \\
(0.101)\end{array}$ & $\begin{array}{l}-0.589 \\
(0.182)\end{array}$ & $\begin{array}{l}-0.028 \\
(0.928)\end{array}$ & $\begin{array}{l}0.249 \\
(0.353)\end{array}$ & $\begin{array}{l}0.190 \\
(0.066)\end{array}$ \\
\hline LnInflation & $\begin{array}{l}-0.031 \\
(0.742)\end{array}$ & $\begin{array}{l}-0.065 \\
(0.750)\end{array}$ & $\begin{array}{l}-0.080 \\
(0.520)\end{array}$ & $\begin{array}{l}-0.058 \\
(0.654)\end{array}$ & $\begin{array}{l}0.175 \\
(0.116)\end{array}$ & $\begin{array}{l}0.085 \\
(0.107)\end{array}$ & $\begin{array}{l}-0.044 \\
(0.638)\end{array}$ & $\begin{array}{l}-0.047 \\
(0.836)\end{array}$ & $\begin{array}{l}-0.105 \\
(0.469)\end{array}$ & $\begin{array}{l}-0.082 \\
(0.484)\end{array}$ & $\begin{array}{l}0.128 \\
(0.274)\end{array}$ & $\begin{array}{l}0.084 * \\
(0.053)\end{array}$ \\
\hline LnInfrastructure & $\begin{array}{l}0.422 * * * \\
(0.008)\end{array}$ & $\begin{array}{l}0.689 * \\
(0.075)\end{array}$ & $\begin{array}{l}0.409 * \\
(0.064)\end{array}$ & $\begin{array}{l}0.506 \\
(0.012)\end{array}$ & $\begin{array}{l}0.215 \\
(0.231)\end{array}$ & $\begin{array}{l}0.049 \\
(0.552)\end{array}$ & $\begin{array}{l}0.408 * * \\
(0.011)\end{array}$ & $\begin{array}{l}0.663 \\
(0.125)\end{array}$ & $\begin{array}{l}0.433 * \\
(0.088)\end{array}$ & $\begin{array}{l}0.513 * * * \\
(0.005)\end{array}$ & $\begin{array}{l}0.238 \\
(0.173)\end{array}$ & $\begin{array}{l}0.032 \\
(0.649)\end{array}$ \\
\hline LnXrate (Exchange rate) & $\begin{array}{l}-0.028 \\
(0.506)\end{array}$ & $\begin{array}{l}0.005 \\
(0.959)\end{array}$ & $\begin{array}{l}-0.071 \\
(0.169)\end{array}$ & $\begin{array}{l}-0.017 \\
(0.713)\end{array}$ & $\begin{array}{l}0.023 \\
(0.618)\end{array}$ & $\begin{array}{l}0.013 \\
(0.433)\end{array}$ & $\begin{array}{l}-0.030 \\
(0.474)\end{array}$ & $\begin{array}{l}-0.011 \\
(0.926)\end{array}$ & $\begin{array}{l}-0.067 \\
(0.257)\end{array}$ & $\begin{array}{l}-0.029 \\
(0.496)\end{array}$ & $\begin{array}{l}0.016 \\
(0.719)\end{array}$ & $\begin{array}{l}0.012 \\
(0.521)\end{array}$ \\
\hline Ln (Political globalisation) & $\begin{array}{l}1.612 * * * \\
(0.006)\end{array}$ & $\begin{array}{l}2.720 * * \\
(0.016)\end{array}$ & $\begin{array}{l}1.998 * * * \\
(0.005)\end{array}$ & $\begin{array}{l}1.631 * * \\
(0.018)\end{array}$ & $\begin{array}{l}0.283 \\
(0.646)\end{array}$ & $\begin{array}{l}0.302 \\
(0.313)\end{array}$ & $\begin{array}{l}1.607 * * * \\
(0.006)\end{array}$ & $\begin{array}{l}3.248 * * \\
(0.010)\end{array}$ & $\begin{array}{l}1.798 * * \\
(0.028)\end{array}$ & $\begin{array}{l}1.635 * * * \\
(0.008)\end{array}$ & $\begin{array}{l}0.447 \\
(0.451)\end{array}$ & $\begin{array}{l}0.265 \\
(0.274)\end{array}$ \\
\hline Civil Conflicts & $\begin{array}{l}0.104 \\
(0.257)\end{array}$ & $\begin{array}{l}-0.059 \\
(0.780)\end{array}$ & $\begin{array}{l}0.074 \\
(0.512)\end{array}$ & $\begin{array}{l}0.035 \\
(0.733)\end{array}$ & $\begin{array}{l}0.177 \\
(0.044)\end{array}$ & $\begin{array}{l}0.138 * * * \\
(0.000)\end{array}$ & $\begin{array}{l}0.088 \\
(0.325)\end{array}$ & $\begin{array}{l}-0.0009 \\
(0.997)\end{array}$ & $\begin{array}{l}0.082 \\
(0.531)\end{array}$ & $\begin{array}{l}0.011 \\
(0.896)\end{array}$ & $\begin{array}{l}0.151 \\
(0.101)\end{array}$ & $\begin{array}{l}0.109 * * * \\
(0.002)\end{array}$ \\
\hline Pseudo $\mathrm{R}^{2} / \mathrm{R}^{2}$ & 0.063 & 0.120 & 0.072 & 0.040 & 0.038 & 0.050 & 0.065 & 0.118 & 0.072 & 0.043 & 0.035 & 0.046 \\
\hline Fisher & $3.21 * * *$ & & & & & & $3.45 * * *$ & & & & & \\
\hline Observations & 448 & 448 & 448 & 448 & 448 & 448 & 448 & 448 & 448 & 448 & 448 & 448 \\
\hline
\end{tabular}

Panel B: Unclear Terrorism and Total Terrorism

Unclear Terrorism (Unclter)

Total Terrorism (Totter)

\begin{tabular}{|c|c|c|c|c|c|c|c|c|c|c|c|c|}
\hline & OLS & Q.10 & Q.25 & Q.50 & Q.75 & Q.90 & OLS & Q.10 & Q.25 & Q.50 & Q.75 & Q.90 \\
\hline \multirow[t]{2}{*}{ Constant } & $-5.457 * *$ & $-14.7 * * *$ & $-7.904 * *$ & $-6.934 *$ & 1.539 & $2.846 * *$ & $-5.650 * *$ & - & $-8.166^{* *}$ & $-7.437 * *$ & 1.440 & $2.923 * *$ \\
\hline & $(0.042)$ & $(0.008)$ & $(0.019)$ & $(0.057)$ & $(0.510)$ & $(0.028)$ & $(0.034)$ & $\begin{array}{l}14.24 * * * \\
(0.005)\end{array}$ & $(0.012)$ & $(0.013)$ & $(0.646)$ & $(0.012)$ \\
\hline Unclter & $\begin{array}{l}0.073 \\
(0.450)\end{array}$ & $\begin{array}{l}0.074 \\
(0.618)\end{array}$ & $\begin{array}{l}-0.009 \\
(0.914)\end{array}$ & $\begin{array}{l}0.211^{*} \\
(0.096)\end{array}$ & $\begin{array}{l}0.042 \\
(0.482)\end{array}$ & $\begin{array}{l}\mathbf{0 . 1 3 3} * * * \\
(\mathbf{0 . 0 0 0})\end{array}$ & --- & --- & --- & --- & --- & --- \\
\hline Totter & --- & --- & --- & --- & --- & --- & $\begin{array}{l}0.006 \\
(0.541)\end{array}$ & $\begin{array}{l}0.005 \\
(0.735)\end{array}$ & $\begin{array}{l}-0.0007 \\
(0.935)\end{array}$ & $\begin{array}{l}0.022 * \\
(0.065)\end{array}$ & $\begin{array}{l}0.004 \\
(0.587)\end{array}$ & $\begin{array}{l}-0.005 * * \\
(0.043)\end{array}$ \\
\hline LnBilaid & $\begin{array}{l}0.114 \\
(0.388)\end{array}$ & $\begin{array}{l}0.692 * * \\
(0.012)\end{array}$ & $\begin{array}{l}0.365 * * \\
(0.021)\end{array}$ & $\begin{array}{l}0.275 \\
(0.110)\end{array}$ & $\begin{array}{l}-0.221 * \\
(0.095)\end{array}$ & $\begin{array}{l}-0.177 * * \\
(0.010)\end{array}$ & $\begin{array}{l}0.117 \\
(0.386)\end{array}$ & $\begin{array}{l}0.648 * * \\
(0.015)\end{array}$ & $\begin{array}{l}0.388 * * \\
(0.012)\end{array}$ & $\begin{array}{l}0.252 * \\
(0.081)\end{array}$ & $\begin{array}{l}-0.234 \\
(0.165)\end{array}$ & $\begin{array}{l}-0.192 * * * * \\
(0.001)\end{array}$ \\
\hline Unclter * LnBilaid & -0.014 & -0.011 & -0.001 & $-0.037 *$ & -0.012 & $\begin{array}{l}- \\
0.028 * * * \\
(0.000)\end{array}$ & --- & --- & --- & --- & --- & --- \\
\hline Totter* LnBilaid & --- & --- & --- & --- & --- & --- & $\begin{array}{l}-0.001 \\
(0.474)\end{array}$ & $\begin{array}{l}-0.0002 \\
(0.941)\end{array}$ & $\begin{array}{l}-0.0002 \\
(0.872)\end{array}$ & $\begin{array}{l}-0.003 \\
(0.102)\end{array}$ & $\begin{array}{l}-0.001 \\
(0.385)\end{array}$ & $\begin{array}{l}0.0004 \\
(0.409)\end{array}$ \\
\hline LnTrade & $\begin{array}{l}-0.326 \\
(0.241)\end{array}$ & $\begin{array}{l}-1.146 * \\
(0.079)\end{array}$ & $\begin{array}{l}-0.571 \\
(0.193)\end{array}$ & $\begin{array}{l}-0.288 \\
(0.465)\end{array}$ & $\begin{array}{l}0.207 \\
(0.375)\end{array}$ & $\begin{array}{l}0.184 \\
(0.119)\end{array}$ & $\begin{array}{l}-0.298 \\
(0.282)\end{array}$ & $\begin{array}{l}-1.093^{*} \\
(0.074)\end{array}$ & $\begin{array}{l}-0.560 \\
(0.128)\end{array}$ & $\begin{array}{l}-0.134 \\
(0.678)\end{array}$ & $\begin{array}{l}0.229 \\
(0.454)\end{array}$ & $\begin{array}{l}0.157 \\
(0.144)\end{array}$ \\
\hline LnInflation & $\begin{array}{l}-0.038 \\
(0.676)\end{array}$ & $\begin{array}{l}0.002 \\
(0.991)\end{array}$ & $\begin{array}{l}-0.091 \\
(0.462)\end{array}$ & $\begin{array}{l}-0.036 \\
(0.802)\end{array}$ & $\begin{array}{l}0.145 \\
(0.149)\end{array}$ & $\begin{array}{l}0.074 * \\
(0.087)\end{array}$ & $\begin{array}{l}-0.032 \\
(0.733)\end{array}$ & $\begin{array}{l}-0.021 \\
(0.913)\end{array}$ & $\begin{array}{l}-0.079 \\
(0.526)\end{array}$ & $\begin{array}{l}-0.056 \\
(0.639)\end{array}$ & $\begin{array}{l}0.173 \\
(0.168)\end{array}$ & $\begin{array}{l}0.086 * * \\
(0.046)\end{array}$ \\
\hline
\end{tabular}




\begin{tabular}{|c|c|c|c|c|c|c|c|c|c|c|c|c|}
\hline LnInfrastructure & $\begin{array}{l}0.419 * * * \\
(0.009)\end{array}$ & $\begin{array}{l}0.726 * \\
(0.082)\end{array}$ & $\begin{array}{l}0.417 * \\
(0.055)\end{array}$ & $\begin{array}{l}0.536 * * \\
(0.017)\end{array}$ & $\begin{array}{l}0.233 \\
(0.131)\end{array}$ & $\begin{array}{l}0.012 \\
(0.887)\end{array}$ & $\begin{array}{l}0.422 * * * \\
(0.008)\end{array}$ & $\begin{array}{l}0.749 * \\
(0.058)\end{array}$ & $\begin{array}{l}0.423 * * \\
(0.046)\end{array}$ & $\begin{array}{l}0.479 * * \\
(0.010)\end{array}$ & $\begin{array}{l}0.221 \\
(0.278)\end{array}$ & $\begin{array}{l}0.052 \\
(0.460)\end{array}$ \\
\hline LnXrate (Exchange rate) & $\begin{array}{l}-0.029 \\
(0.496)\end{array}$ & $\begin{array}{l}0.028 \\
(0.802)\end{array}$ & $\begin{array}{l}-0.078 \\
(0.128)\end{array}$ & $\begin{array}{l}0.002 \\
(0.964)\end{array}$ & $\begin{array}{l}0.019 \\
(0.634)\end{array}$ & $\begin{array}{l}0.005 \\
(0.764)\end{array}$ & $\begin{array}{l}-0.028 \\
(0.502)\end{array}$ & $\begin{array}{l}0.021 \\
(0.843)\end{array}$ & $\begin{array}{l}-0.073 \\
(0.135)\end{array}$ & $\begin{array}{l}-0.024 \\
(0.589)\end{array}$ & $\begin{array}{l}0.022 \\
(0.678)\end{array}$ & $\begin{array}{l}0.014 \\
(0.340)\end{array}$ \\
\hline Ln (Political globalisation) & $\begin{array}{l}1.604 * * * \\
(0.006)\end{array}$ & $\begin{array}{l}2.940 * * * \\
(0.009)\end{array}$ & $\begin{array}{l}1.868 * * * \\
(0.007)\end{array}$ & $\begin{array}{l}1.676 * * \\
(0.027)\end{array}$ & $\begin{array}{l}0.272 \\
(0.601)\end{array}$ & $\begin{array}{l}0.289 \\
(0.300)\end{array}$ & $\begin{array}{l}\text { 1.614*** } \\
(0.006)\end{array}$ & $\begin{array}{l}2.819 * * * \\
(0.008)\end{array}$ & $\begin{array}{l}1.883 * * * \\
(0.005)\end{array}$ & $\begin{array}{l}\text { 1.734**** } \\
(\mathbf{0 . 0 0 6 )}\end{array}$ & $\begin{array}{l}0.281 \\
(0.687)\end{array}$ & $\begin{array}{l}0.283 \\
(0.246)\end{array}$ \\
\hline Civil Conflicts & $\begin{array}{l}0.109 \\
(0.176)\end{array}$ & $\begin{array}{l}0.024 \\
(0.897)\end{array}$ & $\begin{array}{l}0.060 \\
(0.564)\end{array}$ & $\begin{array}{l}0.059 \\
(0.577)\end{array}$ & $\begin{array}{l}0.169 * * \\
(0.020)\end{array}$ & $\begin{array}{l}0.101 * * * \\
(0.000)\end{array}$ & $\begin{array}{l}0.106 \\
(0.251)\end{array}$ & $\begin{array}{l}-0.056 \\
(0.786)\end{array}$ & $\begin{array}{l}0.064 \\
0.552)\end{array}$ & $\begin{array}{l}0.039 \\
(0.675)\end{array}$ & $\begin{array}{l}0.178^{*} \\
(0.077)\end{array}$ & $\begin{array}{l}0.139 * * * \\
(0.000)\end{array}$ \\
\hline $\begin{array}{l}\text { Pseudo } \mathrm{R}^{2} / \mathrm{R}^{2} \\
\text { Fisher }\end{array}$ & $\begin{array}{l}0.065 \\
\mathbf{3 . 3 1} * * *\end{array}$ & 0.118 & 0.073 & 0.041 & 0.041 & $\begin{array}{l}0.053 \\
\mathbf{3 . 2 1} * * *\end{array}$ & 0.0638 & 0.119 & 0.073 & 0.041 & 0.039 & 0.050 \\
\hline Observations & 448 & 448 & 448 & 448 & 448 & 448 & 448 & 448 & 448 & 448 & 448 & 448 \\
\hline
\end{tabular}

***,***: significance levels of $10 \%, 5 \%$ and $1 \%$ respectively. Bilaid: Bilateral aid. OLS: Ordinary Least Squares. $\mathrm{R}^{2}$ for OLS and Pseudo $\mathrm{R}^{2}$ for quantile regression. Lower quantiles (e.g., Q 0.1) signify nations where Fuel Exports is least.

Table 2: Fuel Exports, Multilateral aid, Terrorism

\begin{tabular}{|c|c|c|c|c|c|c|c|c|c|c|c|c|}
\hline & \multicolumn{12}{|c|}{ Dependent Variable: Fuel Exports } \\
\hline & \multicolumn{12}{|c|}{ Panel A: Domestic Terrorism and Transnational Terrorism } \\
\hline & \multicolumn{6}{|c|}{ Domestic Terrorism (Domter) } & \multicolumn{6}{|c|}{ Transnational Terrorism (Tranater) } \\
\hline & OLS & Q.10 & Q.25 & Q.50 & Q.75 & Q.90 & OLS & Q.10 & Q.25 & Q.50 & Q.75 & Q.90 \\
\hline Constant & $\begin{array}{l}-5.567 * * \\
(0.032)\end{array}$ & $\begin{array}{l}- \\
15.35 * * * \\
(0.004)\end{array}$ & $\begin{array}{l}-9.75 * * * \\
(0.003)\end{array}$ & $\begin{array}{l}-7.24 * * * \\
(0.004)\end{array}$ & $\begin{array}{l}1.028 \\
(0.722)\end{array}$ & $\begin{array}{l}1.290 \\
(0.404)\end{array}$ & $\begin{array}{l}-5.586 * * \\
(0.032)\end{array}$ & $\begin{array}{l}- \\
16.24 * * * \\
(0.005)\end{array}$ & $\begin{array}{l}- \\
11.26 * * * \\
(0.002)\end{array}$ & $\begin{array}{l}-7.181 * * * \\
(0.002)\end{array}$ & $\begin{array}{l}2.533 \\
(0.417)\end{array}$ & $\begin{array}{l}1.184 \\
(0.451)\end{array}$ \\
\hline Domter & $\begin{array}{l}\text { 0.006** } \\
(0.044)\end{array}$ & $\begin{array}{l}0.011 \\
(0.303)\end{array}$ & $\begin{array}{l}0.009 \\
(0.122)\end{array}$ & $\begin{array}{l}0.008 \\
(0.158)\end{array}$ & $\begin{array}{l}-0.001 \\
(0.779)\end{array}$ & $\begin{array}{l}0.004 * * * \\
(0.006)\end{array}$ & --- & --- & --- & --- & --- & --- \\
\hline Tranater & --- & --- & --- & --- & --- & --- & $\begin{array}{l}0.039 * \\
(0.086)\end{array}$ & $\begin{array}{l}0.042 \\
(0.672)\end{array}$ & $\begin{array}{l}0.067 \\
(0.142)\end{array}$ & $\begin{array}{l}0.046 \\
(0.190)\end{array}$ & $\begin{array}{l}-0.005 \\
(0.908)\end{array}$ & $\begin{array}{l}-0.046 * * * \\
(0.000)\end{array}$ \\
\hline LnMulaid & -0.173 & $\begin{array}{l}-0.136 \\
(0.677)\end{array}$ & -0.093 & $\begin{array}{l}-0.179 \\
(0.100)\end{array}$ & $\begin{array}{l}-0.324 * * \\
(0.010)\end{array}$ & $\begin{array}{l}- \\
0.202 * * * \\
(0.000)\end{array}$ & -0.173 & -0.169 & -0.135 & $-0.215^{* *}$ & $-0.353 * *$ & $-0.231 * * *$ \\
\hline Domter* LnMulaid & $\begin{array}{l}-0.001 * * \\
(0.029)\end{array}$ & $\begin{array}{l}-0.001 \\
(0.715)\end{array}$ & $\begin{array}{l}-0.002 \\
(0.156)\end{array}$ & $\begin{array}{l}-0.002 * \\
(0.069)\end{array}$ & $\begin{array}{l}-0.0008 \\
(0.526)\end{array}$ & $\begin{array}{l}- \\
0.002 * * * \\
(0.000)\end{array}$ & --- & --- & --- & --- & --- & --- \\
\hline Tranater* LnMulaid & --- & --- & --- & --- & --- & --- & $\begin{array}{l}-0.011^{*} \\
(0.086)\end{array}$ & $\begin{array}{l}-0.003 \\
(0.822)\end{array}$ & $\begin{array}{l}-0.014 \\
(0.225)\end{array}$ & $\begin{array}{l}-0.012 \\
(0.206)\end{array}$ & $\begin{array}{l}-0.007 \\
(0.527)\end{array}$ & $\begin{array}{l}0.010 * \\
(0.063)\end{array}$ \\
\hline LnTrade & $\begin{array}{l}-0.363 \\
(0.193)\end{array}$ & $\begin{array}{l}-0.930 \\
(0.216)\end{array}$ & $\begin{array}{l}-0.728 * \\
(0.062)\end{array}$ & $\begin{array}{l}-0.219 \\
(0.414)\end{array}$ & $\begin{array}{l}0.232 \\
(0.402)\end{array}$ & $\begin{array}{l}0.373 * * \\
(0.010)\end{array}$ & $\begin{array}{l}-0.337 \\
(0.227)\end{array}$ & $\begin{array}{l}-1.013 \\
(0.201)\end{array}$ & $\begin{array}{l}-0.531 \\
(0.230)\end{array}$ & $\begin{array}{l}-0.183 \\
(0.464)\end{array}$ & $\begin{array}{l}0.133 \\
(0.659)\end{array}$ & $\begin{array}{l}0.357 * * \\
(0.013)\end{array}$ \\
\hline LnInflation & $\begin{array}{l}-0.038 \\
(0.696)\end{array}$ & $\begin{array}{l}-0.435 * \\
(0.077)\end{array}$ & $\begin{array}{l}-0.094 \\
(0.458)\end{array}$ & $\begin{array}{l}-0.028 \\
(0.780)\end{array}$ & $\begin{array}{l}0.141 \\
(0.267)\end{array}$ & $\begin{array}{l}0.109^{*} \\
(0.081)\end{array}$ & $\begin{array}{l}-0.036 \\
(0.704)\end{array}$ & $\begin{array}{l}-0.347 \\
(0.176)\end{array}$ & $\begin{array}{l}-0.061 \\
(0.667)\end{array}$ & $\begin{array}{l}-0.002 \\
(0.977)\end{array}$ & $\begin{array}{l}0.078 \\
(0.568)\end{array}$ & $\begin{array}{l}0.107 \\
(0.071)\end{array}$ \\
\hline LnInfrastructure & $\begin{array}{l}0.221 \\
(0.216)\end{array}$ & $\begin{array}{l}0.313 \\
(0.530)\end{array}$ & $\begin{array}{l}0.084 \\
(0.725)\end{array}$ & $\begin{array}{l}0.327^{*} \\
(0.052)\end{array}$ & $\begin{array}{l}0.091 \\
(0.650)\end{array}$ & $\begin{array}{l}0.009 \\
(0.934)\end{array}$ & $\begin{array}{l}0.213 \\
(0.232)\end{array}$ & $\begin{array}{l}0.255 \\
(0.613)\end{array}$ & $\begin{array}{l}0.042 \\
(0.871)\end{array}$ & $\begin{array}{l}0.192 \\
(0.214)\end{array}$ & $\begin{array}{l}0.086 \\
(0.696)\end{array}$ & $\begin{array}{l}-0.015 \\
(0.887)\end{array}$ \\
\hline LnXrate (Exchange rate) & $\begin{array}{l}-0.005 \\
(0.908)\end{array}$ & $\begin{array}{l}-0.080 \\
(0.549)\end{array}$ & $\begin{array}{l}-0.058 \\
(0.269)\end{array}$ & $\begin{array}{l}0.048 \\
(0.211)\end{array}$ & $\begin{array}{l}0.060 \\
(0.228)\end{array}$ & $\begin{array}{l}0.019 \\
(0.315)\end{array}$ & $\begin{array}{l}-0.005 \\
(0.905)\end{array}$ & $\begin{array}{l}-0.077 \\
(0.566)\end{array}$ & $\begin{array}{l}-0.066 \\
(0.279)\end{array}$ & $\begin{array}{l}0.033 \\
(0.363)\end{array}$ & $\begin{array}{l}0.082 \\
(0.139)\end{array}$ & $\begin{array}{l}0.028 \\
(0.272)\end{array}$ \\
\hline Ln (Political globalisation) & $\begin{array}{l}2.052 * * * \\
(0.001)\end{array}$ & $\begin{array}{l}4.332 * * * \\
(0.001)\end{array}$ & $\begin{array}{l}3.142 * * * \\
(0.000)\end{array}$ & $\begin{array}{l}2.270 * * * \\
(\mathbf{0 . 0 0 0 )}\end{array}$ & $\begin{array}{l}0.448 \\
(0.488)\end{array}$ & $\begin{array}{l}0.419 \\
(0.241)\end{array}$ & $\begin{array}{l}2.033 * * * \\
(0.001)\end{array}$ & $\begin{array}{l}4.670 * * * \\
(0.001)\end{array}$ & $\begin{array}{l}3.346 * * * \\
(0.000)\end{array}$ & $\begin{array}{l}2.319 * * * \\
(0.000)\end{array}$ & $\begin{array}{l}0.235 \\
(0.735)\end{array}$ & $\begin{array}{l}0.488 \\
(0.167)\end{array}$ \\
\hline Civil Conflicts & $\begin{array}{l}0.135 \\
(0.144)\end{array}$ & $\begin{array}{l}0.099 \\
(0.676)\end{array}$ & $\begin{array}{l}0.124 \\
(0.259)\end{array}$ & $\begin{array}{l}0.207 * * \\
(0.010)\end{array}$ & $\begin{array}{l}0.079 \\
(0.401)\end{array}$ & $\begin{array}{l}0.180 * * * \\
(0.000)\end{array}$ & $\begin{array}{l}0.118 \\
(0.178)\end{array}$ & $\begin{array}{l}0.125 \\
(0.623)\end{array}$ & $\begin{array}{l}0.124 \\
(0.319)\end{array}$ & $\begin{array}{l}0.106 \\
(0.134)\end{array}$ & $\begin{array}{l}0.070 \\
(0.490)\end{array}$ & $\begin{array}{l}0.109 * * \\
(0.018)\end{array}$ \\
\hline $\begin{array}{l}\text { Pseudo } \mathrm{R}^{2} / \mathrm{R}^{2} \\
\text { Fisher }\end{array}$ & $\begin{array}{l}0.074 \\
\mathbf{5 . 3 8} * * *\end{array}$ & 0.114 & 0.074 & 0.047 & 0.056 & 0.062 & $\begin{array}{l}0.073 \\
\mathbf{4 . 7 3}^{* * *}\end{array}$ & 0.110 & 0.073 & 0.046 & 0.054 & 0.054 \\
\hline Observations & 444 & 444 & 444 & 444 & 444 & 444 & 444 & 444 & 444 & 444 & 444 & 444 \\
\hline
\end{tabular}


Panel B: Unclear Terrorism and Total Terrorism

Unclear Terrorism (Unclter) Total Terrorism (Totter)

\begin{tabular}{|c|c|c|c|c|c|c|c|c|c|c|c|c|}
\hline & OLS & Q.10 & Q.25 & Q.50 & Q.75 & Q.90 & OLS & Q.10 & Q.25 & Q.50 & Q.75 & Q.90 \\
\hline Constant & $\begin{array}{l}-5.485 * * \\
(0.036)\end{array}$ & $\begin{array}{l}- \\
17.04 * * * \\
(0.003)\end{array}$ & $\begin{array}{l}- \\
10.07 * * * \\
(0.001)\end{array}$ & $-7.43 * * *$ & $(0.240)$ & $(0.295)$ & $-5.547 * *$ & $\begin{array}{l}- \\
15.25 * * * \\
(0.004)\end{array}$ & $-9.86 * * *$ & $-7.510 * * *$ & $(0.706)$ & $(0.420)$ \\
\hline Unclter & $\begin{array}{l}0.053 * * \\
(0.020)\end{array}$ & $\begin{array}{l}0.142 * \\
(0.055)\end{array}$ & $\begin{array}{l}\mathbf{0 . 0 8 4} * * \\
(\mathbf{0 . 0 1 4})\end{array}$ & $\begin{array}{l}0.055 \\
(0.174)\end{array}$ & $\begin{array}{l}-0.013 \\
(0.786)\end{array}$ & $\begin{array}{l}0.0006 \\
(0.961)\end{array}$ & --- & --- & --- & --- & --- & --- \\
\hline Totter & --- & --- & --- & --- & --- & --- & $\begin{array}{l}0.005 * * \\
(0.037)\end{array}$ & $\begin{array}{l}0.009 \\
(0.248)\end{array}$ & $\begin{array}{l}0.007 \\
(0.070)\end{array}$ & $\begin{array}{l}0.006 \\
(0.129)\end{array}$ & $\begin{array}{l}0.0001 \\
(0.966)\end{array}$ & $\begin{array}{l}0.003 * * * \\
(0.003)\end{array}$ \\
\hline LnMulaid & $\begin{array}{l}-0.176 \\
(0.128)\end{array}$ & -0.086 & -0.121 & $\begin{array}{l}-0.181 * \\
(0.095)\end{array}$ & $\begin{array}{l}- \\
0.331 * * * \\
(\mathbf{0 . 0 0 4 )}\end{array}$ & $\begin{array}{l}- \\
0.210 * * * \\
(0.000)\end{array}$ & -0.170 & -0.138 & -0.112 & $-0.171 *$ & $\begin{array}{l}- \\
0.324 * * * \\
(0.009)\end{array}$ & $-0.206 * * *$ \\
\hline Unclter * LnMulaid & $\begin{array}{l}- \\
0.011 * * * \\
(0.001)\end{array}$ & $\begin{array}{l}-0.022 \\
(0.111)\end{array}$ & $\begin{array}{l}- \\
0.017 * * * \\
(0.008)\end{array}$ & -0.011 & -0.002 & $\begin{array}{l}- \\
0.006 * * * \\
(0.000)\end{array}$ & --- & --- & --- & --- & --- & --- \\
\hline Totter* LnMulaid & --- & --- & --- & --- & --- & --- & $\begin{array}{l}-0.001 * * \\
(0.018)\end{array}$ & $\begin{array}{l}-0.0007 \\
(0.703)\end{array}$ & $\begin{array}{l}-0.001 * \\
(0.099)\end{array}$ & $\begin{array}{l}-0.002 * \\
(0.053)\end{array}$ & $\begin{array}{l}-0.001 \\
(0.372)\end{array}$ & $\begin{array}{l}-0.002 * * * \\
(0.000)\end{array}$ \\
\hline LnTrade & $\begin{array}{l}-0.363 \\
(0.192)\end{array}$ & $\begin{array}{l}-1.009 \\
(0.196)\end{array}$ & $\begin{array}{l}-0.740 * * \\
(0.034)\end{array}$ & $\begin{array}{l}-0.217 \\
(0.431)\end{array}$ & $\begin{array}{l}0.073 \\
(0.781)\end{array}$ & $\begin{array}{l}0.371 * * * \\
(0.005)\end{array}$ & $\begin{array}{l}-0.367 \\
(0.190)\end{array}$ & $\begin{array}{l}-0.922 \\
(0.222)\end{array}$ & $\begin{array}{l}-0.730 * \\
(0.060)\end{array}$ & $\begin{array}{l}-0.230 \\
(0.374)\end{array}$ & $\begin{array}{l}0.216 \\
(0.432)\end{array}$ & $\begin{array}{l}0.374 * * * \\
(0.008)\end{array}$ \\
\hline LnInflation & $\begin{array}{l}-0.045 \\
(0.633)\end{array}$ & $\begin{array}{l}-0.268 \\
(0.286)\end{array}$ & $\begin{array}{l}-0.084 \\
(0.489)\end{array}$ & $\begin{array}{l}-0.011 \\
(0.914)\end{array}$ & $\begin{array}{l}0.062 \\
(0.592)\end{array}$ & $\begin{array}{l}0.098 * \\
(0.054)\end{array}$ & $\begin{array}{l}-0.039 \\
(0.688)\end{array}$ & $\begin{array}{l}-0.452 * \\
(0.068)\end{array}$ & $\begin{array}{l}-0.082 \\
(0.512)\end{array}$ & $\begin{array}{l}-0.018 \\
(0.853)\end{array}$ & $\begin{array}{l}0.125 \\
(0.314)\end{array}$ & $\begin{array}{l}0.107 * \\
(0.090)\end{array}$ \\
\hline LnInfrastructure & $\begin{array}{l}0.208 \\
(0.244)\end{array}$ & $\begin{array}{l}0.383 \\
(0.455)\end{array}$ & $\begin{array}{l}0.037 \\
(0.864)\end{array}$ & $\begin{array}{l}0.198 \\
(0.247)\end{array}$ & $\begin{array}{l}0.128 \\
(0.503)\end{array}$ & $\begin{array}{l}0.001 \\
(0.987)\end{array}$ & $\begin{array}{l}0.221 \\
(0.215)\end{array}$ & $\begin{array}{l}0.295 \\
(0.537)\end{array}$ & $\begin{array}{l}0.036 \\
(0.875)\end{array}$ & $\begin{array}{l}0.285^{*} \\
(0.077)\end{array}$ & $\begin{array}{l}0.099 \\
(0.615)\end{array}$ & $\begin{array}{l}0.005 \\
(0.962)\end{array}$ \\
\hline LnXrate (Exchange rate) & $\begin{array}{l}- \\
\mathbf{0 . 0 0 3} * * * \\
(0.000)\end{array}$ & $\begin{array}{l}-0.049 \\
(0.714)\end{array}$ & -0.063 & $(0.532)$ & $(0.129)$ & $(0.237)$ & $(0.904)$ & $\begin{array}{l}-0.087 \\
(0.514)\end{array}$ & $\begin{array}{l}-0.056 \\
(0.281)\end{array}$ & $(0.354)$ & $\begin{array}{l}0.062 \\
(0.207)\end{array}$ & $\begin{array}{l}0.020 \\
(0.470)\end{array}$ \\
\hline Ln (Political globalisation) & $\begin{array}{l}2.043 * * * \\
(0.001)\end{array}$ & $\begin{array}{l}4.671 * * * \\
(0.001)\end{array}$ & $\begin{array}{l}3.279 * * * \\
(0.000)\end{array}$ & $\begin{array}{l}2.382 * * * \\
(0.000)\end{array}$ & $\begin{array}{l}0.096 \\
(0.875)\end{array}$ & $\begin{array}{l}0.364 \\
(0.254)\end{array}$ & $\begin{array}{l}2.049 * * * \\
(0.001)\end{array}$ & $\begin{array}{l}4.317 * * * \\
(0.001)\end{array}$ & $\begin{array}{l}3.199 * * * \\
(0.000)\end{array}$ & $\begin{array}{l}2.361 * * * \\
(0.000)\end{array}$ & $\begin{array}{l}0.456 \\
(0.471)\end{array}$ & $\begin{array}{l}0.433 \\
(0.212)\end{array}$ \\
\hline Civil Conflicts & $\begin{array}{l}0.103 \\
(0.185)\end{array}$ & $\begin{array}{l}0.055 \\
(0.792)\end{array}$ & $\begin{array}{l}0.090 \\
(0.315)\end{array}$ & $\begin{array}{l}0.042 \\
(0.558)\end{array}$ & $\begin{array}{l}0.067 \\
(0.420)\end{array}$ & $\begin{array}{l}0.122 * * * \\
(0.000)\end{array}$ & $\begin{array}{l}0.134 \\
(0.144)\end{array}$ & $\begin{array}{l}0.090 \\
(0.704)\end{array}$ & $\begin{array}{l}0.127 \\
(0.258)\end{array}$ & $\begin{array}{l}0.163 * * \\
(0.033)\end{array}$ & $\begin{array}{l}0.085 \\
(0.367)\end{array}$ & $\begin{array}{l}0.183 * * * \\
(0.000)\end{array}$ \\
\hline $\begin{array}{l}\text { Pseudo } \mathrm{R}^{2} / \mathrm{R}^{2} \\
\text { Fisher }\end{array}$ & $\begin{array}{l}0.075 \\
7.25 * * *\end{array}$ & 0.116 & 0.077 & 0.0482 & 0.054 & 0.058 & $\begin{array}{l}0.074 \\
\mathbf{5 . 6 0}^{* * * *}\end{array}$ & 0.114 & 0.074 & 0.048 & 0.057 & 0.062 \\
\hline Observations & 444 & 444 & 444 & 444 & 444 & 444 & 444 & 444 & 444 & 444 & 444 & 444 \\
\hline
\end{tabular}

*,**,***: significance levels of $10 \%, 5 \%$ and $1 \%$ respectively. Mulaid: Multilateral aid. OLS: Ordinary Least Squares. $\mathrm{R}^{2}$ for OLS and Pseudo $\mathrm{R}^{2}$ for quantile regression. Lower quantiles (e.g., Q 0.1) signify nations where Fuel Exports is least.

The following findings can be established from Table 2 on linkages between fuel exports, multilateral aid and terrorism dynamics. First, the effects of terrorism are consistently significant in the highest and lowest quintiles, especially with: (i) positive effects in the $90^{\text {th }}$ deciles for total terrorism and domestic terrorism; (ii) a negative impact in the $90^{\text {th }}$ decile for transnational terrorism and (iii) positive impacts in the $10^{\text {th }}$ decile and $25^{\text {th }}$ quartile for unclear terrorism. Second, multilateral aid steadily decreases fuel exports at the top quantiles $\left(50^{\text {th }}\right.$ to $90^{\text {th }}$ ) for the most part. Third, interaction effects between multilateral aid and terrorism dynamics are significantly negative, but for transnational terrorism in the RHS of Panel A. Moreover, the corresponding modifying thresholds of multilateral aid are within the range provided by the summary statistics, particularly: -1.249 to 7.105 . Accordingly, there is: (i) a negative threshold of $2.000(0.004 / 0.002)$ for domestic terrorism in the $90^{\text {th }}$ decile; (ii) a positive threshold of $4.600(0.046 / 0.010)$ for transnational terrorism in the $90^{\text {th }}$ decile; (iii) a negative threshold of $4.941(0.084 / 0.017)$ for unclear terrorism in the $25^{\text {th }}$ quartile and (iv) 
a negative threshold of $1.500(0.003 / 0.002)$ for total terrorism in the $90^{\text {th }}$ decile. Fourth, the discourse on the significant control variables is consistent with that on Table 1.

\subsection{Further discussion and policy implications}

We discuss the findings in more depth along three main lines: (i) the dynamic impact of terrorism, (ii) the effects of foreign aid dynamics and (iii) the diverging thresholds from interactive effects between foreign aid and terrorism on fuel exports.

First, the effects of terrorism are both positive and negative across quintiles and specifications, with the impact most apparent in the highest and lowest quantiles. This implies that terrorism affects fuel exports in countries with the highest and lowest initial levels of fuel exports. While the effect of total terrorism is mixed because it is negative (positive) in bilateral (multilateral) aid regressions, the impact of unclear, domestic and transnational terrorism is not definite in sign, albeit, at differing quantiles across bilateral and multilateral aid regressions. Evidence of causality flowing from terrorism to fuel exports is broadly in accordance with a stream of the engaged literature, particularly Nitsch and Schumacher (2004); Richardson (2004) and De Sousa et al. (2009ab).

Second, while bilateral aid persistently decreases (increases) fuel exports at the top (bottom) quantiles, multilateral aid consistently decreases fuel exports at the top quantiles. It follows that foreign aid decreases fuel exports in countries with initially very high exports of fuel while bilateral aid increases it in countries where initial export levels are relatively low. Two puzzling concerns boldly standout: (i) the issue of why bilateral aid is positively significant in bottom quantiles as opposed to multilateral aid and (ii) the concern of why foreign aid in high fuel exporting countries has a negative outcome on the dependent variable. (1) With the first concern, the relative effectiveness of bilateral aid vis-à-vis multilateral aid is consistent with the narratives of Asongu et al. (2015) on the political economy of development assistance. According to this study, the strings tied to bilateral aid entail relatively less conflicting interests. Conversely, with multilateral aid, there are more contradictory objectives between donors at play. Hence, the corresponding difficulty in consensus-building among donors may eventually lead to less appealing significant effects on development outcomes. Whereas a recent survey of the literature has been inconclusive on significant differences in terms of development outcomes for bilateral aid vis-à-vis multilateral aid (Biscaye et al., 2015), the basis for our interpretation is deeply rooted in the documented evidence that former colonial powers preserve various strategic interests in 
former colonies and hence can more effectively allocate development assistance towards fighting terrorism and boosting natural resource exports ${ }^{3}$. Contemporary examples include the recent military intervention of France in the Central African Republic and Mali on the one hand and the exploitation of uranium in Niger following the latest presidential elections (Melly \& Darracq, 2013). As a policy implication, relative to multilateral aid, bilateral aid more positively influences fuel exports in low-fuel exporting countries.

(2) On the concern as to why foreign aid generally reduces fuel exports in highexporting countries, we think that sampled countries within the high-end of the distribution may find it strategically relevant to decrease their volume of fuel exports, given that government revenue and other needed finance may already have been boosted by foreign aid external flows. As a policy implication, while bilateral aid should be encouraged in stimulating fuel exports in low-exporting countries, the use and composition of multilateral aid flows should also be changed in order to reverse their negative effect on fuel exports in high-exporting countries.

Third, we have established that, but for negative thresholds in the $50^{\text {th }}$ quartile and $90^{\text {th }}$ decile, interaction effects between bilateral aid and terrorism dynamics are overwhelmingly not significant. Conversely, but for transnational terrorism, the interaction effects between multilateral aid and terrorism dynamics significantly have negative thresholds. It follows that a positive threshold is only confirmed for transnational terrorism and multilateral aid at the $90^{\text {th }}$ decile. The overwhelming negative interaction effect may be traceable to the negative effect of foreign aid on the dependent variable, especially in high-fuel exporting countries. As a policy implication, it is important to first establish the nexus between foreign aid and fuel exports before employing the former to mitigate the potentially negative effect of terrorism on the latter.

Consistent with the motivation of this study which has been partially based on the need to compare results with previous studies that have employed the same periodicity and sample, we briefly engage in how our findings improve the existing literature on linkages between macroeconomic indicators and terrorism. First, it is important to note that (i)

\footnotetext{
${ }^{3}$ The stance on conflicting donor interest is in line with the conclusions of Asongu (2014d) "Aid is the outcome of bargaining in a kind of political market made up of donor aid bureaucracies, multilateral aid agencies and recipient government officials. Indeed donors pursue multiple goals and these vary over time. For instance, economic gains seem important in Japanese aid, global welfare improvement in Nordic aid and political goals in French aid. Hence, few would object to the inference that our findings may also be explained by a motivation of the French to maintain their colonial legacies and influence in Africa" (p. 472).
} 
Bandyopadhyay et al (2014) and Efobi et al (2015) have used the Generalised Method of Moments (GMM) and (ii) Asongu et al. (2015) have used a QR strategy to assess how foreign aid could be used to mitigate the negative effect of terrorism on FDI. While Efobi et al. (2015) have extended Bandyopadhyay et al. (2014) using a more robust GMM technique and conditioning the nexuses on corruption-control levels in recipient countries, Asongu et al. (2015) have extended the two underlying studies by using QR to assess the relationships throughout the conditional distributions of FDI.

It should be noted that the results of latter studies have not been in support of Bandyopadhyay et al. (2014), especially, on (i) an exclusively negative terrorism-FDI nexus and (ii) a positive impact on FDI from aid-terrorism interactions. Results of the present study have improved existing knowledge in this stream of literature by: (i) employing fuel exports as the dependent variable; (ii) partially validating the results of Bandyopadhyay et al. (2014) on the impact of aid, terrorism and corresponding interactions on macroeconomic indicators and (iii) partially confirming the positions of Efobi et al. (2015) and Asongu et al. (2015) that the underlying effects of the independent indicators of interest on macroeconomic variables cannot be a priori established from intuition because they depend on, among others, the dependent variable, methodology and distribution of the dependent variable.

\section{3 Managerial implications for multinational companies}

It is apparent from intuition that terrorism increases the cost of the risk of doing business, regardless of the nature of the business. Conversely, we have established in the study that (i) terrorism could both positively and negatively affect fuel exports and (ii) the potentially instrumental role of foreign aid in mitigating the effect of terrorism on fuel exports does not withstand empirical scrutiny.

While the negative effects of terrorism on fuel exports are consistent with the intuition motivating the study, we have also established that terrorism has a positive influence on fuel exports in some quantiles. This tendency is supported by the findings of De Sousa et al. (2009b) who established that remote terrorism positively affects some dynamics of trade. Moreover, on a more substantive note, the intuition for the positive effect has basis in the assumption that some investors in natural resources may be inclined to invest more in the fuel industry if they anticipate higher returns in the short-, medium- and long-terms, relative to the present risk of terrorism. More contemporary examples with which to substantiate this proposition include: (i) growing investments from China in the Nigerian Delta region despite 
evolving threats from the Movement for the Emancipation of the Niger Delta (MEND) (Obi, 2008) and (ii) China's unrelenting presence in South Sudan, in spite of growing violence, essentially because crude oil from South Sudan accounts for about 5 percent of fuel imports into China (Aguirre, 2014). This interpretation follows from Elu and Price (2010) on China's long-term strategy, which entails an oil diplomacy requiring continuous engagement with countries that are characterised by violence, internal/civil conflicts and political strife.

As a policy implication, terrorism may induce positive effects on some commodity exports. Managers of MNCs should therefore be aware of the fact that terrorism may either positively or negatively influence fuel exports and in situations where the effect is negative, development assistance may not be so much of an instrumental policy tool in dampening the perilous effects on fuel exports. Hence, it is up to these MNCs to take the necessary measures to decrease the negative effects of terrorism on their business operations. Given that MNCs are often the target of terrorism, especially in oil-rich countries, engaging in corporate practices that are friendly to human rights and environmental protection could send a positive signal to the population that the MNCs have inclusive and sustainable development plans for local communities. Improving Corporate Social Responsibility standards is a step in this direction.

Whereas terrorism may not unequivocally disrupt fuel exports as has been established in this study, MNCs need to take preventive steps in order to reduce potentially damaging effects on their cost of doing business. Five main preventive measures may be exploited. First, the amelioration of physical security embodies equipment, plant and personnel, especially in places of higher risks. Second, security consultants often provide very valuable insights into politico-economic risks associated with areas in which MNCs are operating. Such insights are important for informed decision-making. Third, since the global supply chains of MNCs may be exposed to attacks, improving security in transportation networks is vital, though very difficult. Fourth, a measure by which MNCs can mitigate cost could be to reduce and/or avoid investment in areas that are likely to be heavily affected by terrorism. Fifth, uncertainty associated with politically-risky investment environments can be mitigated by subscribing to insurance schemes.

\section{Conclusion and Further Research}

This study has employed quantile regressions to assess the conditional role of foreign aid in reducing the potentially negative effect of terrorism on fuel exports in 78 developing 
counties for the period 1984-2008. Bilateral and multilateral aid indicators have been used whereas terrorism has included: domestic, transnational, unclear and total terrorism dynamics. The following findings have been established. First, the effects of terrorism are both positive and negative across quantiles and specifications, with the impact most apparent in the highest and lowest quantiles. Second, while bilateral aid consistently decreases (increases) fuel exports at the top (bottom) quantiles, multilateral aid consistently decreases fuel exports in the top quantiles. Third, but for negative thresholds in the $50^{\text {th }}$ quartile and $90^{\text {th }}$ decile, interaction effects between bilateral aid and terrorism dynamics are overwhelmingly not significant. Conversely, but for transnational terrorism, the interaction effects between multilateral aid and terrorism dynamics significantly have negative thresholds. The hypothesis of a positive threshold is only confirmed for transnational terrorism and multilateral aid at the $90^{\text {th }}$ decile. Justifications for unexpected signs have been discussed.

Four main inferences have been established: (i) terrorism may induce positive effects on some commodity exports, (ii) relative to multilateral, bilateral aid more positively influences fuel exports in low-fuel exporting countries, (iii) while bilateral aid should be encouraged in stimulating fuel exports in low-exporting countries, the composition and use of multilateral foreign aid should also be re-structured in order to reverse its negative effect on fuel exports in high-exporting countries and (iv) it is important to first establish the connection between foreign aid and fuel exports before employing the former to mitigate the potentially negative effect of terrorism on the latter.

The resulting managerial implications which are consistent with Oh and Oetzel (2016) can be summarised in the following. Since, terrorism augments social unrest and imposes additional costs to the doing of business; managers of Multinational Companies (MNCs) can more effectively lessen the potentially damaging effects on their operations by leveraging on the experience of host governments in the mitigation of negative externalities of terrorism on development outcomes. One approach by which host governments could fight terrorism is by reliance on foreign aid flows. In the absence of robust evidence that such foreign aid can be instrumental for the purpose of reducing terrorism, MNCs need to consolidate preventive measures.

There is obviously room for further research in (i) assessing channels through which terrorism negatively and positively influences fuel exports and (ii) distinguishing development assistance by sectors in order to improve the extant of knowledge on how aidspecific categories influence the established interconnections. 


\section{Appendices}

\section{Appendix 1: Definition and source of variables}

\begin{tabular}{|c|c|c|c|}
\hline Variables & Signs & Definitions & Sources \\
\hline Fuel Export & FuelExp & Ln. Fuel Export (as a \% of Merchandise Export) & \multirow{13}{*}{$\begin{array}{l}\text { Bandyopadhyay } \\
\text { et al. (2014) } \\
\text { and Efobi et al. } \\
(2015)\end{array}$} \\
\hline Trade Openness & LnTrade & Ln. of Exports plus Imports of Commodities ( $\%$ of GDP) & \\
\hline Infrastructure & LnTel & Ln. of Number of Telephone lines (per 100 people) & \\
\hline Inflation & LnInflation & Ln. of Consumer Price Index (\% of annual) & \\
\hline Exchange rate & LnXrate & Ln. of Exchange rate (local currency per USD) & \\
\hline Bilateral Aid & LnBilaid & Ln. of Bilateral aid, net disbursement (million USD) & \\
\hline Multilateral Aid & LnMulaid & Ln. of Multilateral aid, net disbursement (million USD) & \\
\hline Domestic terrorism & Domter & Number of Domestic terrorism incidents & \\
\hline $\begin{array}{l}\text { Transnational } \\
\text { terrorism }\end{array}$ & Tranater & Number of Transnational terrorism incidents & \\
\hline Unclear terrorism & Unclter & Number of terrorism incidents whose category is unclear & \\
\hline Total terrorism & Totter & Total number of terrorism incidents & \\
\hline $\begin{array}{l}\text { Political } \\
\text { globalisation }\end{array}$ & LnPolglob & Ln. of Index of political globalisation & \\
\hline Internal conflicts & Civcon & Index of internal civil conflicts & \\
\hline
\end{tabular}

GDP: Gross Domestic Product. WDI: World Development Indicators.

\section{Appendix 2: Summary statistics}

\begin{tabular}{lccccc}
\hline & Mean & S.D & Minimum & Maximum & Obs \\
\cline { 2 - 6 } Fuel Export (ln) & 1.007 & 2.785 & -11.366 & 4.585 & 503 \\
Trade Openness (ln) & 4.118 & 0.534 & 2.519 & 5.546 & 612 \\
Infrastructure (ln) & 1.475 & 1.017 & 0.091 & 4.031 & 616 \\
Inflation (ln) & 2.414 & 1.384 & -3.434 & 9.136 & 581 \\
Exchange rate (ln) & 2.908 & 3.870 & -22.121 & 21.529 & 618 \\
Bilateral Aid (ln) & 5.181 & 1.286 & 0.765 & 8.362 & 602 \\
Multilateral Aid (ln) & 4.163 & 1.518 & -1.249 & 7.105 & 600 \\
Domestic terrorism & 14.292 & 45.179 & 0 & 419.33 & 624 \\
Transnational terrorism & 2.316 & 6.127 & 0 & 63 & 624 \\
Unclear terrorism & 1.972 & 7.479 & 0 & 86 & 624 \\
Total terrorism & 18.581 & 55.595 & 0 & 477.66 & 624 \\
Political globalisation (ln) & 4.036 & 0.301 & 2.861 & 4.530 & 624 \\
Internal conflicts & 0.965 & 1.906 & 0 & 10 & 615 \\
\hline S.D: Standard Deviat
\end{tabular}

S.D: Standard Deviation. Obs: Observations. 


\section{Appendix 3: Correlation Matrix}

\begin{tabular}{|c|c|c|c|c|c|c|c|c|c|c|c|c|c|}
\hline LnFuelExp & LnTrade & LnTel & LnInflation & LnXrate & LnBilad & LnMulaid & Domter & Tranater & Unclter & Totter & LnPolglob & Civcon & \\
\hline \multirow[t]{13}{*}{1.000} & -0.106 & 0.095 & 0.016 & -0.002 & 0.230 & -0.090 & 0.044 & 0.066 & 0.013 & 0.044 & 0.207 & 0.043 & LnFuelExp \\
\hline & 1.000 & 0.296 & -0.230 & 0.043 & -0.267 & -0.289 & -0.236 & -0.206 & -0.240 & -0.246 & -0.122 & -0.299 & LnTrade \\
\hline & & 1.000 & -0.121 & -0.191 & -0.376 & -0.514 & 0.023 & 0.072 & -0.003 & 0.026 & 0.268 & -0.183 & LnTel \\
\hline & & & 1.000 & -0.284 & -0.047 & -0.023 & 0.171 & 0.164 & 0.091 & 0.169 & -0.150 & 0.185 & LnInflation \\
\hline & & & & 1.000 & 0.114 & 0.183 & -0.081 & -0.001 & -0.050 & -0.073 & 0.089 & -0.120 & LnXrate \\
\hline & & & & & 1.000 & 0.721 & 0.116 & 0.088 & 0.093 & 0.117 & 0.233 & 0.259 & LnBilaid \\
\hline & & & & & & 1.000 & 0.014 & -0.039 & 0.069 & 0.016 & 0.167 & 0.194 & LnMulaid \\
\hline & & & & & & & 1.000 & 0.743 & 0.733 & 0.993 & 0.127 & 0.428 & Domter \\
\hline & & & & & & & & 1.000 & 0.528 & 0.785 & 0.120 & 0.418 & Tranater \\
\hline & & & & & & & & & 1.000 & 0.789 & 0.072 & 0.347 & Unclter \\
\hline & & & & & & & & & & 1.000 & 0.126 & 0.441 & Totter \\
\hline & & & & & & & & & & & 1.000 & -0.024 & LnPolglob \\
\hline & & & & & & & & & & & & 1.000 & Civcon \\
\hline
\end{tabular}

LnFuelExp: Fuel Export. LnTrade: Trade Openness. LnTel: Number of Telephone lines. LnXrate: Exchange rate. LnBilaid: Bilateral aid. LnMulaid: Multilater aid. LnTotaid: Total aid. Domter: Number of Domestic terrorism incidents. Tranater: Number of Transnational terrorism incidents. Unclter: Number of terrorism incidents whose category in unclear. Totter: Total number of terrorism incidents. LnPolglob: Index of political globalisation. Civcon: Index of internal civil conflicts. 


\section{References}

Abadie, A., \& Gardeazabal, J., (2008. "Terrorism and the world economy", European Economic Review, 52(1), pp.1-27.

Aguirre, I., (2014). "Violence in South Sudan Threatens Chinese Oil Investment", Global Risk Insights http://oilprice.com/Energy/Crude-Oil/Violence-In-South-Sudan-Threatens-Chinese-OilInvestment.html (Accessed: 11/07/2015).

Agwu, E. M., \& Taylor, A. R., (2015). CSR as a Strategic Management Tool: Expectations and Realities of Two MNCs in Nigeria in Human Rights and Ethics: Concepts,

Methodologies, Tools, and Applications (Chapter 44), pp. 795-811, IGI Global: Hershey.

Akinwale, A. K., (2010). "Integrating the traditional and the modern conflict management strategies in Nigeria”, Department of Sociology, Faculty of Social Sciences, University of Ibadan, Nigeria.

Akpan, U., (2014). "Impact of Regional Road Infrastructure Improvement on Intra-Regional Trade in ECOWAS", African Development Review, 16(S1), pp. 64-76.

Akpan, U., Essien, M., \& Isihak, S., (2013). "The impact of rural electrification on rural micro-enterprises in Niger Delta, Nigeria”, Energy for Sustainable Development, 17(5), pp. 504-509.

Al-Khouri, R., (2015). "Determinants of foreign direct and indirect investment in the MENA region”, Multinational Business Review, 23(2), pp. 148-166.

Alon, I., \& Martin, M. A., (1998). "A normative model of macroeconomic risk assessment", Multinational Business Review, 6(2), pp. 10-19.

Amavilah, V. H., (2015). "Social Obstacles to Technology, Technological Change, and the Economic Growth of African Countries: Some Anecdotal Evidence from Economic History", MPRA Paper No. 63273.

Anderson, M., (2015), "Global cost of conflict reaches $\$ 14.3 \mathrm{tn}$, says report", The guardian, http://www.theguardian.com/global-development/2015/jun/16/global-cost-conflict-reaches14tn-says-report (Accessed: 27/06/2015).

Arellano, M., \& Bover, O., (1995). "Another Look at the Instrumental Variable Estimation of Error Component Model”. .Journal of Econometrics, 68(1), pp. 29-52.

Asongu, S. A., (2013). "Fighting corruption in Africa: do existing corruption-control levels matter?", International Journal of Development Issues, 12(1), pp. 36-52.

Asongu, S. A., Anyanwu, J. C., \& Tchamyou, V. S., (2017). "Technology-driven information sharing and conditional financial development in Africa", Information Technology for Development. DOI: 10.1080/02681102.2017.1311833. 
Asongu, S. A., Efobi, U., \& Beecroft, I., (2015). "FDI, Aid, Terrorism: Conditional Threshold Evidence from Developing Countries", African Governance and Development Institute Working Paper No. 15/019, Yaoundé.

Asongu. S. A., \& Nwachukwu, J. C., (2017). "The synergy of financial sector development and information sharing in financial access: Propositions and empirical evidence", Research in International Business and Finance, 40(April), pp. 242-258.

Baltagi, B. H., (2008). "Forecasting with panel data", Journal of Forecasting, 27(2), pp. 153173.

Bandyopadhyay, S., Sandler, T., \& Younas, J., (2014). "Foreign direct investment, aid, and terrorism”, Oxford Economic Papers, 66(1), pp. 25-50.

Bader, B., \& Berg, N., (2014a). "An Empirical Investigation of Terrorism-induced Stress on Expatriate Attitudes and Performance", Journal of International Management, 19(2), pp. 163175.

Bader, B., \& Berg, N., (2014b). "The influence of terrorism on expatriate performance: a conceptual approach", International Journal of Human Resource Management, 25(4), pp. 539-557.

Bader, B., Schuster, T., \& Dickmann, M., (2015). "Special issue of International Journal of Human Resource Management: Danger and risk as challenges for HRM: how to manage people in hostile environments", International Journal of Human Resource Management, 26(15), pp. 2015-2017.

Bader, A. K., Reade, C., \& Froese, F. J., (2016). "Terrorism and expatriate withdrawal cognitions: the differential role of perceived work and non-work constraints", The International Journal of Human Resource Management, DOI: 10.1080/09585192.2016.1233448.

Beets, S. D., (2005). "Understanding the Demand-Side Issues of International Corruption." Journal of Business Ethics, 57 (1), pp. 65-81.

Bell, S. R., Clay, K. C., Murdie, A., \& Piazza, J., (2014). "Opening Yourself Up: The Role of External and Internal Transparency in Terrorism Attacks", Political Research Quarterly: doi:10.1177/1065912914527798.

Billger, S. M., \& Goel, R. K., (2009), "Do existing corruption levels matter in controlling corruption? Cross-country quantile regression estimates", Journal of Development Economics, 90, pp. 299-305.

Biscaye, P., Harris, K. P., Reynolds, T., \& Anderson, C. L., (2015). "Relative Effectiveness of Bilateral and Multilateral Aid on Development and Social Outcomes", Evans School of Policy Analysis and Research (EPAR) Brief No. 294, Seattle, Washington.

Black, D., (1990). The elementary forms of conflict management. New York, Plenum Press. 
Borg, M. J., (1992). "Conflict management in the modern world-system". Sociological Forum, 7(2), pp. 261-282.

Brambor, T., Clark, W. M., \& Golder, M., (2006), “Understanding Interaction Models: Improving Empirical Analyses", Political Analysis, 14 (1), pp. 63-82.

Brockhoff, S., Kieger, T., \& Meierrieks, D., (2014). "Great Expectations and Hard Times The (Nontrivial) Impact of Education on Domestic Terrorism", Journal of Conflict Resolution: doi: 10.1177/0022002713520589.

Buckley, P. J., \& Boddewyn, J. J., (2015). “The internalization of societal failures by multinational enterprises", Multinational Business Review, 23(3), pp. 170-187.

Caulderwood, K., (2015) "Sub-Saharan Africa Falls Behind In Fight Against Extreme Poverty: World Bank Report", International Business Times (April 14th 2015). http://www.ibtimes.com/sub-saharan-africa-falls-behind-fight-against-extreme-povertyworld-bank-report-1881460 (Accessed: 19/04/2015).

Celso, A. N., (2015). “Zarqawi’s Legacy: Al Qaeda's ISIS “Renegade"”, Mediterranean Quarterly, 26(2), pp. 21-41.

Choi, S-W., (2015). "Economic growth and terrorism: domestic, international, and suicide", Oxford Economic Papers, 67(1), pp. 157-181.

Choi, S-W., (2010). "Fighting Terrorism through the Rule of Law?", The Journal of Conflict Resolution, 54(6), pp. 940-966.

Choi, S-W., \& Salehyan , I., (2013). "No Good Deed Goes Unpunished: Refugees, Humanitarian Aid, and Terrorism", Conflict Management and Peace Sciences, 30(1), pp. 5375 .

Costa, A., Hermandez, M., \& Sebastian-Gallés, N., (2008). "Bilingualism aids conflict resolution: Evidence from the ANT task", Cognition, 106 (1), pp. 59-86.

De Sousa, J., Mirza, D., \& Verdier, T., (2009a), "Trade and the Spillovers of Transnational Terrorism”, Swiss Society of Economics and Statistics, 145 (4), pp. 453-461.

De Sousa, J., Mirza, D., \& Verdier, T., (2009b). “Terrorism Networks and Trade: Does the Neighbor Hurt?”, CEPR Discussion Paper No. DP7946.

Efobi, U., \& Asongu, S. A. (2016). "Terrorism and capital flight from Africa", International Economics, 148(December), pp. 81-94.

Efobi, U., Asongu, S., \& Beecroft, I., (2015). "Foreign Direct Investment, Aid and Terrorism: Empirical Insight Conditioned on Corruption Control", African Governance and Development Institute Working Paper No. 15/007, Yaoundé.

Enders, W., \& Sandler T., (2006). The Political Economy of Terrorism. New York: Cambridge University Press. 
Enders W, Sandler T \& Gaibulloev K., (2011). "Domestic versus transnational terrorism: Data, decomposition, and dynamics”. Journal of Peace Research, 48(3), pp. 319-337.

Elu, J. U., \& Price, G. N., (2010). "Does China Transfer Productivity Enhancing Technology to Sub-Saharan Africa? Evidence from Manufacturing Firms", African Development Review, 22(1), pp. 587-598.

Eubank, N., (2012), "Taxation, Political Accountability and Foreign Aid: Lessons from Somaliland", Journal of Development Studies, 48(4), pp. 465-480.

Feridun, M., \& Shahbaz, M., (2010). "Fighting Terrorism: Are Military Measures Effective? Empirical Evidence from Turkey”, Defence \& Peace Economics, 21(2), pp. 193-205.

Gaibulloev, K., \& Sandler, T., (2008). "The adverse effect of transnational and domestic terrorism on growth in Africa", Journal of Peace Research, 48(3), pp. 355-371.

Gaibulloev, K., \& Sandler, T., (2009). "The impact of terrorism and conflicts on growth in Asia”, Economics and Politics, 21(3), pp. 359-383.

Gaibulloev, K., \& Sandler, T., (2011). "Growth Consequences of Terrorism in Western Europe", Kyklos, 61(3), pp. 411-424.

Gailbulloev, K., Sandler, T., \& Santifort, C., (2012). “Assessing the Evolving Threat of Terrorism", Global Policy, 3(2), pp. 135-144.

Gardner, K. L., (2007). "Fighting Terrorism the FATF Way". Global Governance: A Review of Multilateralism and International Organisation, 13(3), pp. 325-345.

Gaub, F., (2014). "The EU and Libya and the Art of the Possible", The International Spectator: Italian Journal of International Affairs, 49(3), pp. 40-53.

Gault, J., Spierer, C., Bertholet, J-L., \& Karbassioun, B., (1999). "How does OPEC allocate quotas?", Journal of Energy Finance and Development, 4(2), pp. 137-148.

GTI (2014). "Global Terrorism Index: Measuring and Understanding the Impact of Terrorism", Institute for Economics and Peace, pp. 2-90.

http://www.visionofhumanity.org/sites/default/files/Global\%20Terrorism\%20Index\%20Repor t\%202014_0.pdf (Accessed: 28/04/2015).

Gries, T., Krieger, T., \& Meierrieks, D., (2011). "Causal Linkages Between Domestic Terrorism and Economic Growth", Defence and Peace Economics, 22(5), pp. 493-508.

Harvey, M., Dabic, M., Kiessling, T., Maley, J., \& Moeller, M., (2017). "Engaging in duty of care: towards a terrorism preparedness plan", The International Journal of Human Resource Management, DOI: 10.1080/09585192.2017.1298651.

Heyneman, S. P., (2002). "Defining the Influence of Education on Social Cohesion", International Journal of Educational Policy, Research and Practice, 3(4), pp. 73-97. 
Heyneman, S. P., (2008a). "Education, social cohesion and ideology. In Right to Education: Policies and Perspectives, edited by Emin Karip, 89-104. Ankara: Turkish Education Association.

Heyneman, S. P., (2008b). "Buying your way into Heaven: The corruption of education systems in global perspective.”, Perspectives on Global Issues, 2 (1), pp. 1-8.

Hoffman, A. M., Shelton, C., \& Cleven, E., (2013). "Press Freedom, Publicity, and the CrossNational Incidence of Transnational Terrorism", Political Research Quarterly, 66 (4), pp. 896-909.

Huang, S., \& John, C., (2017). "FDI Location Choice: The Role of Locational Ambidexterity", Multinational Business Review, 25(1), pp.

Humphreys, M., (2005). "Natural Resources, Conflict, and Conflict Resolution. Uncovering the Mechanisms", Journal of Conflict Resolution, 49 (4), pp. 508-537.

International Country Risk Guide. (2010) The political risk services group, available at http://www.prsgroup.com/icrg.aspx (Accessed 10 October 2010).

Koenker, R., \& Hallock, F.K., (2001), “Quantile regression”, Journal of Economic Perspectives, 15, pp.143-156.

Koh, W. T. H., (2007). "Terrorism and its impact on economic growth and technological innovation”, Technological Forecasting and Social Change, 74(2), pp. 129-138.

Lauring, J., Andersen, P. H., Storgaard, M., \& Kragh, H., (2017). “Low Intensity Conflict in MNCs", Multinational Business Review, 25(1), pp.

Le Billon, P., (2015). "Oil, Secession and the Future of Iraqi Federalism”, Middle East Policy, 22(1), pp. 68-76.

Le Roux, S., \& Kelsey, D., (2015a). "Dragon Slaying with Ambiguity: Theory and Experiments", Sara le Roux, Department of Economics, Oxford Brookes University.

Le Roux, S., \& Kelsey, D., (2015b). "Strategic Substitutes, Complements and Ambiguity: An Experimental Study", Department of Economics, Oxford Brookes University.

Love, I., \& Zicchino, L., (2006). "Financial Development and Dynamic Investment Behaviour: Evidence from Panel VAR" .The Quarterly Review of Economics and Finance, 46(2), pp. 190-210.

Mazzarella, J. J., (2005). "Terrorism and Multinational Corporations: International Business Deals with the Costs of Geopolitical Conflict”, Major Themes in Economics, Spring 2005. http://citeseerx.ist.psu.edu/viewdoc/download?doi=10.1.1.456.9308\&rep=rep1\&type=pdf (Accessed: 21/03/2017). 
Meierrieks, D., \& Gries, T., (2013). "Causality between terrorism and economic growth", Journal of Peace Research, 50(1), pp. 91-104.

Melly, P., \& Darracq, V., (2013). "A New Way to Engage? French Policy in Africa from Sarkozy to Hollande", Catham House, Africa 2013/01, London.

Mirza, D., \& Verdier, T., (2008), "International trade, security and transnational terrorism: Theory and a survey of empirics", Journal of Comparative Economics, 36(2), pp. 179-194.

Nitsch, V., \& Schumacher, D., (2004), “Terrorism and international trade: an empirical investigation”, European Journal of Political Economy, 20(2), pp. 423-433.

Obi, C. I., (2010). "Oil Extraction, Dispossession, Resistance, and Conflict in Nigeria's OilRich Niger Delta”, Canadian Journal of Development Studies, 30(1-2), pp. 219-236.

Öcal, N., and Yildirim, J., (2010). "Regional effects of terrorism on economic growth in Turkey: A geographically weighted regression approach", Journal of Peace Research, 47(4), pp. 477-489.

Oh, C H., \& Oetzel, J., (2016). "Once bitten twice shy? Experience managing violent conflict risk and MNC subsidiary-level investment and expansion", Strategic Management Journal, 38(3), pp. 714-731.

Okada, K., \& Samreth, S.,(2012), "The effect of foreign aid on corruption: A quantile regression approach", Economic Letters, 115(2), pp. 240-243.

Onuoba, F. C., (2010). "Oil pipeline sabotage in Nigeria: Dimensions, actors and implications for national security”, African Security Review, 17(3), pp. 99-115.

Onyeji, I., Brazilian, M., \& Bronk, C., (2014). "Cyber Security and Critical Energy Infrastructure", The Electricity Journal, 27(2), pp. 52-60.

Oreopoulos, P., \& Salvanes, K. G., (2009). "How Large are Returns to Schooling? Hint: Money Isn't Everything.", NBER Working Paper No. 15339.

Piazza, J. A., (2006). "Rooted in Poverty?: Terrorism, Poor Economic Development, and Social Cleavages", Terrorism and Political Violence, 18(1), pp. 159-177.

Piazza, J. A., (2011), "The illicit drug trade, counternarcotics strategies and terrorism", Public Choice, 149(3-4), pp. 297-314.

Piazza, J. A., (2012), "The Opium Trade and Patterns of Terrorism in the Provinces of Afghanistan: An Empirical Analysis", Terrorism and Political Violence, 24(2), pp. 213-234.

Ramcharran, H., (2003). "Estimating the Impact of Risks on Emerging Equity Market Performance: Further Evidence on Data from Rating Agencies", Multinational Business Review, 11(3), pp. 77-90. 
Richardson, M., (2004), “A Time Bomb for Global Trade: Maritime-related Terrorism in an Age of Weapons of Mass Destruction”, Maritime Studies, Volume 2004 (134), pp. 1-8.

Rodrik, D., (2008). "The Real Exchange Rate and Economic Growth", Harvard University, http://www.hks.harvard.edu/fs/drodrik/Research\%20papers/RER\%20and\%20growth.pdf (Accessed: 29/04/2015).

Roodman, D., (2009a). "A Note on the Theme of Too Many Instruments", Oxford Bulletin of Economics and Statistics, 71(1), pp. 135-158.

Roodman, D., (2009b). "How to do xtabond2: An introduction to difference and system GMM in Stata”, Stata Journal, 9(1), pp. 86-136.

Rudra, N., \& Jensen, N. M., (2011). "Globalisation and the Politics of Natural Resources", Comparative Political Studies, 44(6), pp. 639-661.

Shahbaz, M., Shahbaz, S., M., Nasir, M. M., \& Edward, W. M., (2013). "An analysis of a causal relationship between economic growth and terrorism in Pakistan", Economic Modelling, 35(September), pp. 21-29.

Shahzad, S. J. H., Zakaria, M., Rehman, M. U., Ahmed, T., \& Fida, B. A., (2015)

"Relationship Between FDI, Terrorism and Economic Growth in Pakistan: Pre and Post 9/11 Analysis", Social Indicators Research, (March, 2015)

http://link.springer.com/article/10.1007\%2Fs11205-015-0950-5

Singh, P., (2001). "Punjab Terrorism: Truth Still Uncovered", Economic and Political Weekly, 36 (40), pp. 3829-3831.

Singh, P., (2007). "The Political Economy of the Cycles of Violence and Non-violence in the Sikh Struggle for Identity and Political Power: implications for Indian federalism", Third World Quarterly, 28(3), pp. 555-570.

Suder G., \& Czinkota, M., (2005). "Towards An Understanding of Terrorism Risk in the MNE”, Multinational Business Review, 13(3), pp. 3-23.

Taylor, I., (2014). "Chinese interest in Nigeria's oil and the American context", Canadian Journal of African Studies, 48(3), pp. 391-404.

Thomas, K.W., (1992). Conflict and negotiation processes in organisations. In: Dunnette, M.D. and L.M. Hough eds. Handbook of industrial and organisational psychology. Palo Alto, CA, Consulting Psychologists Press. pp. 651-717.

Volkema, R. J., \& Bergmann, T. J., (1995). "Conflict styles as indicators of behavioural patterns in interpersonal conflicts”. The Journal of Social Psychology, 135 (1), pp. 5-15.

World Bank (2015). “World Development Indicators', World Bank Publications http://www.gopa.de/fr/news/world-bank-release-world-development-indicators-2015 (Accessed: 25/04/2015). 